2019-05-01

\title{
Tyrrhenian central Italy: Holocene population and landscape ecology
}

\author{
Stoddart, S
}

http://hdl.handle.net/10026.1/13130

$10.1177 / 0959683619826696$

Holocene

SAGE Publications

All content in PEARL is protected by copyright law. Author manuscripts are made available in accordance with publisher policies. Please cite only the published version using the details provided on the item record or document. In the absence of an open licence (e.g. Creative Commons), permissions for further reuse of content should be sought from the publisher or author. 


\section{The Holocene}

\section{Tyrrhenian central Italy: Holocene population and landscape ecology}

\begin{tabular}{|c|c|}
\hline Journal: & The Holocene \\
\hline Manuscript ID & HOL-18-0129.R1 \\
\hline Manuscript Type: & Paper \\
\hline $\begin{array}{r}\text { Date Submitted by the } \\
\text { Author: }\end{array}$ & $\mathrm{n} / \mathrm{a}$ \\
\hline Complete List of Authors: & $\begin{array}{l}\text { Stoddart, Simon; University of cambridge, Archaeology } \\
\text { Woodbridge, Jessie; University of Plymouth, Geography } \\
\text { Palmisano, Alessio; University College London (UCL), Institute of } \\
\text { Archaeology; } \\
\text { Mercuri, Anna Maria; University of Modena and Reggio Emilia, Life } \\
\text { Sciences } \\
\text { Mensing, Scott; University of Nevada, Reno, Geography } \\
\text { Colombaroli, Daniele; Royal Holloway University of London School of } \\
\text { Biological Sciences, Geography } \\
\text { Sadori, Laura; Sapienza University, Biologia Vegetale } \\
\text { Magri, Donatella; Sapienza University, Dip. Biologia Vegetale } \\
\text { Di Rita, Federico; Sapienza Università di Roma, Dip. Biologia Ambientale; } \\
\text { Giardini, Marco; Sapienza University, Biologia Ambientale } \\
\text { Mariotti, Marta; Università di Firenze, Dipartimento di Biologia Vegetale } \\
\text { Montanari, Carlo; Università di Genova, Dipartimento di Scienze della } \\
\text { Terra, dell'Ambiente e della Vita } \\
\text { Bellini, Cristina; Università di Genova, Laboratorio di Archeologia e Storia } \\
\text { Ambientale; Università di Firenze, Dipartimento di Biologia Vegetale } \\
\text { Florenzano, Assunta; University of Modena and Reggio Emilia, } \\
\text { Department of Life Sciences } \\
\text { Torri, Paola; Universita degli Studi di Modena e Reggio Emilia } \\
\text { Dipartimento di Scienze della Vita } \\
\text { Bevan, Andrew; University College London (UCL), Institute of } \\
\text { Archaeology } \\
\text { Shennan, Stephen; UCL, Institute of Archaeology } \\
\text { Fyfe, Ralph; University of Plymouth, } \\
\text { Roberts, C. Neil; University of Plymouth, Geography }\end{array}$ \\
\hline Keywords: & Pollen, Vegetation, Radiocarbon, Central Italy, demography, settlement \\
\hline Abstract: & $\begin{array}{l}\text { This paper compares changes in vegetation structure and composition } \\
\text { (using synthetic fossil pollen data) with proxy data for population levels } \\
\text { (including settlements and radiocarbon dates) over the course of the last } \\
\text { ten millennia in Tyrrhenian central Italy. These data show generalised } \\
\text { patterns of clearance of woodland in response both to early } \\
\text { agriculturalists and urbanism, as well as the specific adoption of tree } \\
\text { crops and variations in stock grazing. The results provide a } \\
\text { comprehensive understanding of the development of the }\end{array}$ \\
\hline
\end{tabular}


anthropogenised landscape of one of the most important early centres of European civilisation, showing regional trends as well as local variations.

\section{SCHOLARONE ${ }^{m}$ \\ Manuscripts}


Tyrrhenian central Italy: Holocene population and landscape ecology

Stoddart, S1 ${ }^{1}$, Woodbridge, J. ${ }^{2}$, Palmisano, A. ${ }^{3}$, Mercuri, A.-M ${ }^{4}$., Mensing, S. ${ }^{5}$, Colombaroli, D. ${ }^{6}$, Sadori, L. ${ }^{7}$, Magri, D. ${ }^{7}$, di Rita, F. ${ }^{7}$, Giardini, M. ${ }^{7}$, Mariotti Lippi, M. ${ }^{8}$, Montanari, C. ${ }^{9}$, Bellini, C. ${ }^{8}$, Florenzano, A. ${ }^{4}$, Torri, P. ${ }^{4}$, Bevan, A. ${ }^{3}$, Shennan, S. ${ }^{3}$, Fyfe, R. ${ }^{2}$, Roberts, N. ${ }^{2}$

ss16@cam.ac.uk

jessie.woodbridge@plymouth.ac.uk

a.palmisano@ucl.ac.uk

annamaria.mercuri@unimore.it

smensing@unr.edu

Daniele.Colombaroli@rhul.ac.uk

laura.sadori@uniroma1.it

donatella.magri@uniroma1.it

federico.dirita@uniroma1it

marco.giardini@uniroma1.it

marta.mariotti@unifi.it

carlo.montanari@unige.it

cri_mini@yahoo.com

assunta.florenzano@unimore.it

torri.paola@unimore.it

a.bevan@ucl.ac.uk

s.shennan@ucl.ac.uk

ralph.fyfe@plymouth.ac.uk

C.N.Roberts@plymouth.ac.uk

${ }^{1}$ Magdalene College, Cambridge, CB3 OEU, UK

${ }^{2}$ School of Geography, Earth and Environmental Sciences, University of Plymouth, Drake Circus, Plymouth PL48AA, UK

${ }^{3}$ Institute of Archaeology, University College London, 31-34 Gordon Square, London WC1H OPY, UK

${ }^{4}$ Laboratorio di Palinologia e Paleobotanica, Dipartimento di Scienze della Vita, Università di Modena e Reggio Emilia, Italy

${ }^{5}$ Department of Geography, University of Nevada, Reno, NV 89557, USA

${ }^{6}$ Department of Geography, Royal Holloway, University of London, TW20 OEX, UK.

7Dipartimento di Biologia Ambientale, Università di Roma "La Sapienza", Piazzale Aldo Moro, 5, 00185, Roma, Italia

${ }^{8}$ Dipartimento di Biologia, Università di Firenze, Via G. La Pira, 4, 50121 Firenze, Italia

${ }^{9}$ Dipartimento di Scienze della Terra, dell'Ambiente e della Vita, Università di Genova, Genova, Italia

\section{Abstract}

This paper compares changes in vegetation structure and composition (using synthetic fossil pollen data) with proxy data for population levels (including settlements and radiocarbon dates) over the course of the last ten millennia in Tyrrhenian central Italy. These data show generalised patterns of clearance of woodland in response both to early agriculturalists and urbanism, as well as the specific adoption of tree crops and variations in stock grazing. The results provide a comprehensive understanding of the development of the anthropogenised landscape of one of the most important early centres of European civilisation, showing regional trends as well as local variations.

Keywords: Pollen; Vegetation; Radiocarbon; Central Italy; demography; settlement 


\section{Introduction}

This paper investigates the potential effect of changing demography and consequent land use on vegetation cover in the region of Tyrrhenian central Italy between the early Holocene and the postRoman period. To achieve this end, it combines high resolution pollen data as a proxy for vegetation and frequency of radiocarbon dates and frequency/size of settlement sites as a proxy for demography. It critically examines the advantages and difficulties of the large data sets that have been assembled by deploying appropriate statistical techniques. Nevertheless, recognition is given to the complexities of the relationship between numbers of sites and population levels and to the challenge of integrating independent climatic data at this stage of research.

The specific aims of this paper are to compare synthetic pollen data with reconstructed human population levels since the early Holocene for a defined and spatially-congruent region within Tyrrhenian central Italy (Fig. 1). More precisely, archaeological radiocarbon date and site frequencies are proposed as proxies of population change and compared with substantial changes in vegetation and land cover across this region. Significant steps have been taken to harmonise the comparison in a number of ways, most notably by using common 200 -year time intervals, a level of precision that can be accommodated by both the archaeological and palaeoecological data. The data have been addressed at three spatial scales: 1) Tyrrhenian central Italy as a whole, 2) the scale of three subregions and 3 ) the local human community level from examples of site catchments of excavated archaeological sites that are sufficiently coeval with neighbouring pollen catchments of lake deposits. The region of Tyrrhenian central Italy has enough sites to produce regional trends and forms the main body of this paper. The data from sub-regions between the Arno and the Albegna rivers (later North Etruria), between the Albegna and the Tiber (later South Etruria) and between the Tiber and the Garigliano river (later Latium vetus), possess enough data to produce indicative rather than statistically significant trends. Finally, a small number of pollen sites associated with local settlement have been analysed for local developments. A number of important, sufficiently large, data sets have been assembled in this tightly defined region, both by archaeologists and palaeoecologists, to make a powerful interdisciplinary comparison of how and why population levels and vegetation assemblages changed over the last 10,000 years, at least until the end of the Roman period (see Table 1 for the chronological scheme). Thereafter, historical geography is required to bring the knowledge of settlement patterns up to the modern era (e.g. Bertacchi \& Onnis 2004).

A distinctive feature of Tyrrhenian central Italy is that this was the region where two rival urban civilisations, the Etruscans and the Latins, developed over the course of the third millennium BP, with important implications for anthropogenic land use. The growth of population from c. 2900 BP, often concentrated in nucleated centres (Pacciarelli 2000; Fulminante 2014; Stoddart 2016; in press), would have required intensified exploitation of a surrounding landscape. A further distinctive feature is that this anthropogenised landscape emerged out of a setting less affected by human action during the preceding Holocene than some other parts of the Mediterranean: e.g. the Eastern Mediterranean or, for that matter, southern Italy, eastern Sicily or even Adriatic central Italy. Individual high-resolution pollen records from central Italy show intensive land use well before 2900 $\mathrm{BP}$ and development of disturbance-adapted vegetation at the Mesolithic-Neolithic transition, but this was often a very localized effect that was less visible at regional scale. As elsewhere in the 
Mediterranean basin (Mercuri et al. this volume), once initiated, this trend of intensification of land use became more pronounced and generalised, first during the Etruscan period (perhaps in response to the demands of metallurgical production (Mariotti Lippi et al. 2000)) and then in the Roman period, perhaps in a more spatially extensive mode that included both lowlands and uplands. After a decline, another cycle of exploitation began in the Medieval period, and, in the lowlands, in the modern historical past.

One undoubted influence on the patterns detected here is climatic change. The study area of central Italy lies between the latitude of $42^{\circ}$ and $44^{\circ}$ North, just to the south of the Holocene climatic boundary at $45^{\circ}$ North hypothesised by Peyron et al. (2017), but to the north of $40^{\circ} \mathrm{North}$, the boundary originally defined by Magny et al. (2013). As remarked by these authors, this hypothesised boundary is strongly affected by the location of the restricted sample sites (Peyron et al. 2017: 256) where proxies independent of pollen have been deployed for calculating precipitation and temperature. In fact, a synthesis of Mediterranean non-palynological hydroclimate datasets by Finné et al. (this volume) fails to show any clear latitudinal boundary between the Holocene climate trajectory of northern and southern Italy. In spite of these difficulties, it has to be acknowledged that a contributing factor towards the change in vegetation outlined in this article may be a climatic switch during the mid-Holocene, between 7500 and 4000 Cal yr BP (Magny et al. 2012; Roberts et al., 2011). It is difficult at this stage to quantify in detail the changes in vegetation in response to this climatic change, which was governed by considerable regional variation within the broader global pattern (Mayewski et al. 2004), although an outline for key tree taxa across the whole of the Italian peninsula is provided by Magri et al. (2015).

In spite of these reservations, the Mediterranean hydroclimate data synthesis by Finné et al. (this volume) has revealed that records from cave and lake sites located in Italy indicate dry conditions from 10,000 until 8700 cal. yrs. BP. This was followed by a rapid switch toward wetter conditions at some sites (e.g. Lago di Pergusa, Sicily) that persisted until 6900 cal. yrs. BP. However, during this period the Italian pollen records mostly show development of dense forest formations (Magri et al. 2015). A more stable climate seems to have followed, which was then succeeded by a period of increased variation between records suggesting greater sub-regional climatic variability. Two periods when climate may have played a significant role in cultural change were firstly at and after $4200 \mathrm{Cal}$ yr BP, and secondly around $3000 \mathrm{Cal}$ yr BP. The former, the well-known 4.2 ka abrupt climate event, is very clearly marked as a period of aridity in the Grotta di Renella speleothem record from northern Tuscany (Drysdale et al. 2006), and coincides with the transition between the Late Copper Age and the Early Bronze Age. This event is marked by a clear drop in forest cover in southern and central Italy, but is not found in other areas of the Mediterranean Basin (Di Rita et al. 2018). A different pattern can be identified around 3000 Cal yr BP, when most Italian hydro-climatic records indicate relatively wet conditions, at a time when the eastern Mediterranean was notably dry (Finné et al. this volume). This may be relevant to the rapid proto-urbanisation that occurred at the end of the Bronze Age in Italy (see discussion below), although the regional response of vegetation to this climate instability was rather diverse (Di Rita et al. 2018).

\section{Scalar data source criticism}


Tyrrhenian central Italy is defined for the purposes of this paper as bounded by the Arno catchment to the north, the Tiber to the east, as far south as the latitude of Rome, and then by the foothills of the Apennines, until a point at the same latitude of Monte Circeo meeting the sea south of the Pontine marshes along the course of the Garigliano river (Fig. 1).

The region of Tyrrhenian central Italy under consideration divides into three regions on geographical grounds. These same divisions were then consolidated on geopolitical grounds during the formative pre-Roman period, with consequences for all subsequent periods. Latium vetus (Fulminante 2014), the distinct political zone of the Latins (and the off-centre central place of Rome that gave its name to the later Roman empire) was placed to the south of the Tiber, and comprised an important volcanic province to the north with significant lowlands around the Pontine marshes to the south, collectively bordering the Apennine foothills to the east. Etruria itself (Stoddart 2016) to the north of the Tiber is geopolitically divided at this scale into two zones, separated by the Albegna river. To the south, South Etruria is distinguished by primate cities in another volcanic province, which, even if they had distinctive political trajectories and territorial sizes, broadly shared an intensity of urbanisation. To the north, North Etruria had generally a less packed, more dispersed, political landscape in a more varied geography of Plio-Pleistocene deposits, limestones, sandstones and intermontane tectonic valleys. Ideally, it would be prudent to examine these three regions separately as part of the analysis, but the size of the pollen data set does not permit a sub-division into Etruria and Latium Vetus. Cognisant of these limitations in the data, it is also prudent to note that the vegetational impact of the political process of South Etruria may have had more similarity with Latium vetus than with North Etruria, since the first two were the politically and economically most developed areas in the third millennium BP.

At a micro-scale, at least three locations of pollen sites can be interpreted as close to known concentrated settlement activity with excavated detail. In the north, Lago Massaciuccoli (Colombaroli et al. 2007; Mariotti Lippi et al. 2007a; Bellini et al. 2009) is located close to the small Etruscan site of S. Rocchino (Massarosa) (Fornaciari 1978). In the Maremma, Lago di Accesa (Colombaroli et al. 2008; Drescher-Schneider et al. 2007) was very close to the village sized Etruscan settlement of the same name (Camporeale 1997). The newly published Mezzano core (Sadori 2018) was also affected by local settlement activity but was "off-site" in the Etruscan period, illustrating the complexity of vegetational development in the landscape (see further discussion below). In the south, the Alban hills contained both the volcanic lakes of Nemi and Albano (Mercuri et al. 2002) and nucleated Latin sites, such as Alba Longa, Tusculum and Gabii (Guaitoli 1982; Becker et al. 2009). The proximity of such sites to pollen cores allows us to capture not only the general picture of the landscape, but also some of the details of variation in clearance of vegetation in the neighbourhood of concentrations of population.

\section{Methodological source criticism}

\section{Pollen data set}

Pollen data sets from across the Mediterranean region were extracted from the European modern and fossil pollen databases (Davis et al. 2013; Leydet 2007-2017), filtered for quality (including appropriate temporal depth) and enriched by invited contributors (including those provided by authors of this paper). Cluster-based analysis (described below) was used to identify the major spatio-temporal patterns of vegetation change across the entire Mediterranean datasets 
(Woodbridge et al. in press; Fyfe et al. 2018), using complete datasets that have been carefully taxonomically harmonised, amalgamated, chronologically-synthesised and normalised. Taxa below $1 \%$ with fewer than 50 occurrences have been removed in the analysis. We present here the results from 17 fossil pollen sites in our study region, grouped into 55 time windows (11000 BP to modern) (Fig. 1). Three of these original pollen sites (Padule, Colfiorito and Ospitale (Watson 1996)) were subsequently excluded because of their mountainous altitude (above $500 \mathrm{~m}$ ), which also excludes them from a strict definition of Tyrrhenian central Italy. Lago Lungo was also excluded from the regional synthesis because of the dissimilar landscape in which this site is located. The inclusion of these three high altitude sites in the dataset would have resulted in patterns highly influenced by high altitude vegetation, which is not typical of the lower elevation region; therefore combining these dissimilar landscapes together in a regional synthesis was not appropriate. The full Holocene pollen record from Lago di Mezzano (Sadori 2018) was published too late for inclusion in our regional data synthesis, but is discussed in the text below.

\section{Modern and fossil pollen datasets}

Descriptions of the methodological approaches developed and applied to the pollen datasets are provided in Woodbridge et al. (in press) and Fyfe et al. (2018). Pollen sequences with relatively reliable chronologies (Giesecke et al. 2013) were selected for analysis and new sediment core chronologies were constructed for additional records using the 'BACON' R package (Blaauw \& Christen 2011). The pollen count data from each site were summed into 200-year time windows and analyses were applied to the entire Mediterranean region in order to identify key vegetation types. Analyses for a sub-set of 14 fossil pollen sequences (from 11 sites) and 37 modern pollen sites are presented in this paper for central Italy (Table 2).

\section{Pollen data analysis}

An unsupervised data-driven approach was used to assign pollen samples to vegetation cluster groups based on the similarity of their taxa assemblages using Ward's hierarchical agglomerative clustering method (Ward 1963) within the 'rioja' R package (Juggins 2015; see Woodbridge et al. in press and Fyfe et al. 2018) for a detailed description of the cluster analysis approach developed). A phytosociological classification approach was used to identify the frequent and abundant pollen taxa within each cluster group based on their median and interquartile range (IQR). Interpretive name descriptors were given to each vegetation cluster using phytosociological classification tables along with comparisons with other classification systems, land cover types defined by remote sensing and the results of previous studies (see Woodbridge et al. in press). In order to explore major patterns in the pollen datasets, non-metric multidimensional scaling (nMDS) was applied to the data using the $R$ 'vegan' package (Oksanen et al., 2016) and Simpson's diversity index (Simpson 1949) was calculated for each pollen sample. This index, which is frequently used to explore diversity change in pollen datasets (e.g. Morris et al. 2014) was selected because it takes both species richness and evenness into account (Simpson, 1949). Pollen indicator groups were also used to summarise key changes in the datasets. This included calculating the average arboreal pollen sum (\%AP), a sum of tree crop indicators OJC (Olea, Juglans, Castanea) (Mercuri et al. 2013a) (also combined with Vitis: OJCV), calculation of an anthropogenic pollen index (API: Artemisia, Centaurea, Cichorieae and Plantago, cereals, Urtica and Trifolium type) (Mercuri et al. 2013b), and a sum of pastoral indicators (Asteroideae, Cichorioideae, Cirsium-type, Galium-type, Ranunculaceae and Potentilla-type pollen) 
(Mazier et al. 2006). Vegetation cluster group changes were calculated as an average for all sites in the central Italy study region and plotted stratigraphically. Oleaceae was grouped with Olea in the OJC index; within the datasets used in this study occurrences of Oleaceae are thought to represent poorly-preserved Olea. Other taxa in the Oleaceae family are identified separately (e.g. Fraxinus, Phillyrea or Jasminum).

\section{Archaeological radiocarbon dataset}

A total of 697 uncalibrated radiocarbon dates spanning from Late Mesolithic (10,000 BP) to the fall of the Roman Empire (1500 BP) have been identified from 170 sites and either harmonised from online sources and extant databases (e.g. BANADORA (Galate (2011), RADON (Hintz et al. 2012), University of Oxford's ORAU (ORAU 2016), EUROEVOL (Manning et al. 2015)) or, manually input from a wide range of publications such as published reports, journal articles, etc. (see Fig. 1a). All of these radiocarbon dates are from archaeological contexts, with the majority being samples of bone, charcoal and wood (see Palmisano et al. 2018; see also Supplemental material 1 for a full list of original sources). Radiocarbon dates obtained from marine samples such as shell have been removed (and are not part of the above total) to avoid the complicated issues arising from unknown or poorly understood marine reservoir offsets.

The first archaeological proxy for population levels, the summed probability distribution (SPD) of radiocarbon dates, is effective only for the period up to $2500 \mathrm{BP}$. After that, the radiocarbon time series becomes a very unreliable proxy, because classical, medieval and modern archaeologists (and to a lesser extent protohistoric archaeologists covering 3500-2700 BP) have been very reluctant to adopt radiocarbon as a dating technique (e.g starting as far back as Ridgway 1979: 415; Peroni et al 1980, but continuing as a practice). The reasons are historical, educational, financial and practical. Material culture rules the interpretative record of these later periods and time has been ordered into precisely defined relative chronologies tied into historical dates by the cross-dating of imports. Furthermore, scientific analysis has not been part of the educational system for an arts-based archaeology. Radiocarbon dating has, until recently, been costly and perceived to be less accurate. Only since the turn of the millennium, has a combination of dendrochronology (largely external to the area) and increasingly precise AMS dating begun to transform the picture in the period centred around 3000 BP. In addition, the period affected by the 'Hallstatt plateau' in the radiocarbon correction curve (c. 2750-2350 BP) has been very little dated by radiocarbon in central Italy for the sensible reason that samples from this period are not good chronological value for money since the resulting dates on the plateau have larger timespans. In northern Europe, Bayesian approaches have begun to make an impact on the same period (Hamilton et al. 2015), and remain useful because of the relative 'fuzziness' of dating from material culture, but this revolution has yet to hit central Italy or to be perceived as advantageous. For these reasons, the SPD of radiocarbon dates is to be considered reliable for the period between 10,000 and 2500 BP where the broad trends appear to be effective and may even provide a sounder understanding of population levels for the Neolithic $(8,000-6,000 \mathrm{BP})$, than the more difficult interpretation of fragile, broadly dated, pottery from surface survey. 
The probabilities from each calibrated date are combined to produce a summed probability distribution (SPD) ${ }^{1}$. The potential bias of oversampling particular site-phases has been reduced by aggregating multiple uncalibrated radiocarbon dates from the same site that are within 100 years of each other and dividing by the number of dates that fall within this bin (Timpson et al. 2014). Then, the probabilities of each bin are summed: in our case, 697 radiocarbon dates have been grouped into 364 bins. Nevertheless, it is important to point out that this approach is conservative because it is based on the assumption that a higher number of radiocarbon dates for specific site phases derives from research intensity rather than from a larger area of the site in that phase. Following previous works (Williams 2012; Weninger et al. 2015) showing that normalised calibrated dates emphasise narrow artificial peaks in SPDs due to steepening portions of the radiocarbon calibration curve, we opted to use unnormalised dates prior to summation and calibrated via IntCal13 curve (Reimer et al. 2013; see former applications of calibrated unnormalised radiocarbon dates in Bevan et al. 2017; Palmisano et al. 2017; Roberts et al. 2018).

Finally, a logistic null model representing expected population increase has been fitted to the observed SPD in order to produce a $95 \%$ confidence envelope (composed of 1,000 random SPDs) and statistically test if the observed pattern significantly departs from this model (for the general approach, Shennan et al 2013; Timpson et al 2014; as specifically implemented in Bevan and Crema 2018: modelTest, 'uncalsample'for). This theoretical null model of population change builds on the assumption that a population's per capita decreases to zero as population size approaches a maximum imposed by limited resources in the environment as there might be an upper bound to pre-Iron Age population growth. This model was preferred given the observed distributional shape of the SPD of radiocarbon dates in central Italy (see Fig. 2). However, it is important to bear in mind that a logistic model cannot be considered strictly as a realistic model for population growth, but rather as an elementary model useful for quantitatively testing population fluctuations (cf. Turchin 2001). In this case, we preferred a logistic model to other possible null-models (e.g. uniform, exponential) given the observed shape of SPD of radiocarbon dates in our study area (see Fig. 2). Deviations above and below the $95 \%$ confidence limits of the envelope respectively indicate periods of population growth and decline greater than expected according a logistic model of population growth. Finally, a global p-value has been calculated in order to assess the significance of the total area of the observed SPD outside the confidence envelope.

Figure 2 shows the (unnormalised) SPD of radiocarbon dates compared with a 95\% envelope for a logistic null model. Deviations above (in red bands) and below (in blue bands) the null model respectively represent population growth or decline beyond that expected under a long-term logistic trend. The results show a significant overall departure of the SPD of observed data (black solid line) from the envelope of the logistic model $(p=0.001)$, which indicates that population did not grow exponentially from 10,000 to $1,500 \mathrm{BP}$ in central Italy. The population is greater than predicted by the logistic model in the Late Mesolithic between 9.9-9.5 ka BP. Nevertheless, the level of population during the late Mesolithic is low and started increasing after the onset of the Neolithic ( 8000 BP). Population growth (and decline) occurred periodically during the Late Neolithic/Chalcolithic (growth $5.2 \mathrm{ka}-4.8 \mathrm{ka} \mathrm{BP}$; decline 4.8-4.6 ka BP; growth 4.6-4.4 ka BP) and

\footnotetext{
${ }^{1}$ The analysis has been performed in R v. 3.3.3 by using the package rcarbon developed by Bevan and Crema (2018).
} 
decreased significantly between 4.4-3.7 ka BP. An apparent crash in population occurred between 3.7 and $3.5 \mathrm{ka}$ BP (indicated by the vertical blue band). This dramatic change may question some current interpretations of continued growth (Bietti Sestieri 2010; Minniti 2012), and needs further research to confirm the pattern. Population then grew dramatically during the later Bronze Age (3.5 $-2.8 \mathrm{ka} \mathrm{BP}$ ). This measure of population may be more robust than site numbers (Fig $3 b$ ) where fluctuations in site numbers may reflect the difficulty in recognizing specific dated handle types from surface survey particularly during the Recent Bronze Age (Barker \& Stoddart 1994). After this period, the population fluctuated and decreased until the fall of the Roman Empire. This decrease of population during the Roman period indicated by the SPD should be considered unreliable because it will be biased by the fact that archaeologists rely mostly on pottery types and coins to date Roman layers rather than using radiocarbon dating (see above).

\section{Archaeological site data set}

Archaeological sites have been collected via a comprehensive review, standardisation, and synthesis of settlement data from reports and gazetteers of 59 archaeological surveys of differing intensities covering circa 10,000 square km (Palmisano et al. 2018; see also Supplemental material 1; Fig. 1b). A total of 7,074 archaeological sites were divided into 10,758 occupation phases and in what follows they are explored via a set of complementary presentational statistics. For comparison with pollen data, these were then placed into two hundred year time-slices, representing a suitable matching between the estimated occupation history of the archaeological sites and resolution of the pollen chronologies. Estimated settlement size has been recorded per each time-slice in cases where sites have been extensively excavated and/or surveyed methodically. Given the need for reliable data sets only systematic survey data that covered prehistory until the full classical period were selected where available. The analysis with this dataset cannot be continued into the medieval and modern period, since most surveys have a cut off with the classical period (with the notable exception of work by the University of Siena which was initiated by a School of Medieval Archaeology). Historical geography information would be required to take the picture up to the present day, but was not collected for this paper. In addition, certain higher quality survey datasets were also unavailable, notably the British School at Rome South Etruria survey (Patterson et al 2004), the Tuscania survey (Barker and Rasmussen 1988) and the Val Cecina survey (Terrenato 1996). Tuscania had already been considered more extensively by a Forma Italiae study (included here), but the loss of the South Etruria survey is a more pronounced gap. A further issue is that the Bronze Age sites have frequently been collected by a topographically targeted strategy that is distinct from systematic survey (e.g. Barbaro 2010), that probably over-represents the Final Bronze Age when compared with the earlier phases of the Bronze Age. The contributing surveys to the settlement database considered here individually have very particular characteristics which need to be acknowledged even if collectively they do not profoundly affect the overall patterns. One major source of data is the Forma Italiae (e.g. Morselli \& Tortorici 1982) undertaken by classical archaeologists in a series of individual (square) map sheets, often centred on an ancient urban centre. In common with the work of the British School at Rome (di Gennaro \& Stoddart 1982) an acknowledged bias is most probably an under-estimation of prehistoric sites in survey results based on both ceramics and lithics. Another important data source is the work of prehistorians in the suburbs of Rome (Arnoldus Huyzendveld et al. 1993). The Agro Pontino has been well covered by Dutch scholars (Attema 1993). One major 
Etruscan city, Cerveteri, has been explicitly studied, but only in the south eastern approaches (Enei 2001). The Siena school of archaeology has undertaken extensive work in the Scarlino area (Cucini 1985) and in the Chianti region (e.g. Campana 2001), with the most extensive chronological coverage. All the above approaches generally deployed a methodology of continuous coverage. One of the largest surveys was of the boundary area of the Ager Cosanus, and in this case a series of transects were implemented across the Albegna valley (Carandini \& Cambi 2002). The dataset could be criticised for the diversity of these approaches, but the relatively large numbers of sites recovered permits us to hazard the conclusion that the main data trends are trustworthy, since only systematic surveys have been included ${ }^{2}$. Nevertheless, the only periods that can be compared in detail are the classical periods (Etruscan to early Roman), because of the high recognition of central classical material by all surveyors, whereas prehistoric and later Antique material require a particular specialised focus on behalf of the survey teams which was not always present.

In our analysis, we have broken up the settlement evidence into 43 time-slices each lasting 200 years starting with period $\mathrm{t}_{t 1}\left(10,000-9,800 \mathrm{Cal}\right.$ yr BP) and ending with period $\mathrm{t}_{43}(1,600-1,400 \mathrm{Cal} \mathrm{yr} \mathrm{BP})$. Then, we have (a) calculated sites count per time-slice, and (b) have summed the estimated site sizes for each time step in order to assess how the population changes across time every 200 years. Bearing in mind the temporal uncertainty associated with many archaeological sites, particularly sites only found by survey which result in larger or shorter time spans according to the dating precision provided by recovered archaeological artefacts, we have applied a probabilistic approach known as aoristic analysis (see former applications in Crema et al. 2010, 1118-1121; Crema 2012, 446-448; Kolář et al. 2016; Orton at al. 2017; Palmisano et al. 2017, 63-65). In addition, to mitigate the discrepancy between wide chronological uncertainties and narrower likely site durations, we applied Monte Carlo methods to generate randomised start of occupation periods for sites with lowresolution information (cf. Crema 2012; Palmisano et al. 2017: 63-64).

Figure 3 shows the frequency per 200 year time-block of 10,758 site occupation phases. In this analysis, four different proxies derived from archaeological settlement data are presented together to assess demographic trends over the long run: raw site counts, summed settlement areas, aoristic weights, and randomised site occupations. The results for all four proxies show an increase of population at the beginning of the Neolithic ( $8000 \mathrm{BP}$ ) and peaks during the Late Neolithic ( $5.5 \mathrm{ka}$ BP), the Chalcolithic ( 5.3 - $5.1 \mathrm{ka} \mathrm{BP}$ ), in the early Bronze Age (c. 4300 Cal yr BP), the Middle Bronze Age (3.6 - 3.3 ka BP), and the Early Iron Age (3.1 -2.7 ka BP), and the Late Republican/Early Imperial Roman period ( $2100-1900$ Cal yr BP). These peaks are punctuated by deep population declines between 5.0 - 4.5 ka BP and 4.1-3.8 ka BP. The first of these broadly agrees with the radiocarbon evidence (Fig. 2), but the second occurs several hundred years earlier than a similar trough indicated by the radiocarbon evidence (Fig. 2); the second trough may have been affected by the topographically targeted survey strategy which has most probably promoted the importance of the Final Bronze Age (seen in Barbaro 2010), compared with the earlier phases of the Bronze Age. We recognise the considerable debate on the relationship between archaeological record, settlement numbers, settlement size and absolute population numbers (Stoddart 1999; Drennan et al. 2015), but have taken statistical precautions to reduce the uncertainty.

\footnotetext{
${ }^{2}$ For a comprehensive list of archaeological surveys carried out in the study area see Palmisano et al. 2018 and Supplemental material 1.
} 


\section{Statistical comparison of population and vegetation change}

The demographic proxies (SPD of radiocarbon dates, aoristic sum, and raw count, estimated total size) are binned into 200-year time slices to match the time windows used in the analysis of pollen sequences. We also calculated the median of the envelope of the randomised start date of sites, which is the result of 1,000 randomised runs, and binned this into 200-year time slices. This step provides a measurement comparable with the other demographic and environmental proxies. A pairwise Spearman's Rank correlation matrix between pollen indicators and archaeological demographic proxies for the period from 10,000 to 1400 Cal yr BP is given on Table 3. Spearman's correlations between all demographic proxies indicate strong positive correlation ( $p$-value $<0.001$ ) and suggest that the archaeological data depict similar population dynamics over the long run. Pollen indicators such as Olea, OJC, OJCV, API and regional grazing are strongly positively correlated with the demographic proxies, indicating that cultivated trees and pastoral activities increase with a higher population. The percentage of Arboreal pollen (AP) is negatively correlated with population, which means that woodland clearance occurs when population grows. The results here described provide us with a longue durée picture during the Holocene. In order to have a better understanding of the human impact on the landscape, we adopted a moving window approach.

The advantage of this approach is that it does not just provide a single global correlation statistic, but instead allows for the identification of particular periods of correspondence and divergence between human population size and land cover from the Late Mesolithic to the fall of the Roman Empire (10,000 - 1400 Cal yr BP). A 2000 year-time moving window Spearman's correlation has been employed, with ten 200-year bins in each time window. This analysis has been performed for all archaeological proxies versus six pollen indicator groups (see Supplemental Material 2: Tables S1S6). In addition, cross correlation analysis has been performed in order to assess if one time-series "causes" changes in another and if they occur with a defined time-lag between each other (in this case a lag unit of 200 years). Cross-correlation values have been indicated in the Supplemental Material 2 (Tables S1-S6) only for those 2000-year time windows showing significant Spearman's correlations.

The results in Supplemental Material 2 (Table S1) show that population is negatively correlated with arboreal (tree) pollen, especially during the Neolithic when population starts increasing, but tree cover appears to be decreasing, after the introduction of farming. Other strong negative correlations occur in the later periods (LBA, IA and Roman). One archaeological proxy (estimated total area) shows a cross correlation with negative lags $(-1)$ in those time windows encompassing the Neolithic, indicating that the increase of population precedes the decrease of arboreal pollen by 200 years. Nevertheless, it is important to point out that most of the correlations have a lag equal to 0 indicating contemporaneity between demographic trends and vegetation change. This is also due to the fact that our 200-year resolution is quite coarse for assessing successfully if there are time lags between demographic proxies and pollen indicators.

The results in Supplemental Material 2 (Tables S2 and S3) show a strong positive correlation between demographic trends and OJC pollen from the Chalcolithic onwards ( $4600 \mathrm{Cal}$ yr BP and after). In some archaeological proxies, the increase of population delayed by 200 years the increase of OJC pollen. Lesser correlations occur between our population proxy and the Anthropogenic Pollen Index (Supplemental Material 2: Table S5). The SPD of radiocarbon dates show negative 
correlations with the API (Anthropogenic Pollen Index) in the Late Mesolithic and Early Neolithic as well as during a period encompassing the Late Neolithic and the Early Bronze Age ( $\sim 5500-3500$ Cal yr BP). Only one archaeological proxy (Total area) shows a strong positive correlation with the API within a time window encompassing a time period from the Chalcolithic to the Iron Age (4800 $2800 \mathrm{Cal}$ yr BP). Supplemental Material 2 (Table S6) shows strong positive correlations between demographic proxies and regional pastoral indicators in the Neolithic and in the later periods (from Chalcolithic to Early Bronze Age).

\section{Comparative Regional Analysis for Tyrrhenian central Italy (Fig. 4).}

Over the period up to $3000 \mathrm{Cal}$ yr BP, some useful and credible trends can be noted. Population levels were very low until the advent of farming at $\sim 8000$ Cal yr BP. Hunter-gatherer activity is broadly associated with low population levels, except in zones of rich biomass (e.g. NW coast of North America) although hunter-gatherers are known to have engaged in deliberate management of local vegetation (e.g. California) (Kelly 2013). In this period, it can, therefore, be readily assumed that climate rather than human impact was the main external operative factor on the vegetation patterns (Orain et al. 2013). In the subsequent Neolithic period, the pollen record may indicate the presence of human populations when archaeological data do not register the same density. In other contexts, the transition to farming is generally assumed to bring a more incisive impact on vegetation. However, the advent of farming was generally lower in its impact on Tyrrhenian central Italy and later than in the rest of the peninsula (Skeates 1994; Radi Petrinelli Pannocchia 2018). In other parts of the peninsula, there were lighter soils and reliable rain fed agriculture with the construction of major ditched enclosures in zones such as the Tavoliere and the Catania plain (Malone 2003). In Tyrrhenian central Italy, sites tended to be smaller and adopt a broad spectrum exploitation of the landscape close to perennial water sources, particularly lakes and water courses (Malone 2003: 267-8; Fugazzola Delpino et al. 1993; Malone et al. 1992; Bellini et al. 2008; 2009). Emmer wheat and barley were often supplemented by collected foods and sheep/goat, cattle and pig, supplemented by wild boar and red deer hunting. There does appear to have been greater intensity of production in the Later Neolithic and the extension of settlement onto heavier soils, although much of this evidence currently derives from the Adriatic seaboard of central Italy (Malone 2003). Additionally, the patterns detectable in the radiocarbon data allow us tentatively to detect a boom-bust pattern of rising and falling populations which has been identified elsewhere in Europe (Shennan et al. 2013). A similar observation has been made in recent studies of the island of Malta (French et al. in preparation).

The broad trends traced from the archaeological data ring true in terms of wider archaeological understanding: a flat demographic curve until the take-off of urbanism at the end of the second millennium BC. The more detailed analysis (Fig. 4) shows a drop in inferred population at the beginning of the Bronze Age ( $4000 \mathrm{Cal}$ yr BP) and again this matches more general expectations. Nevertheless, the low inferred population of this period contrasts with the situation registered in the Po Plain with the Terramara culture (Cremaschi et al. 2016), and may also be an effect of the selection of sites based on the presence of radiocarbon dates. However, these demographic trends had a less evident impact on the vegetational landscape than the longer term trends responding to the clearance for agriculture. Some of the preference for wet conditions for agriculture, accompanied by a more wide-ranging use of the landscape, may have continued even into the Bronze Age in areas such as the Arno catchment (Mariotti Lippi et al. 2010; Giachi et al. 2010). Most 
importantly, the main increase in tree crops in this region occurred after $2.8 \mathrm{ka}$ BP (i.e. in the Etruscan/Latin period) coincident with a further decline in woodland cover, and this can be related to key changes in olive oil and wine production, detectable in material culture practices and trade, largely from the many tombs of the elite (e.g. Naso 2000; see results in Tables S1-S3). This is clearly reflected by the pollen-derived OJC index for cultivated trees (Fig. 5; Supplemental Material 2: Table S3). The direct evidence is tantalisingly scarce because of the lack of systematic flotation of archaeological deposits, but carbonised seeds of grape and olive have been found from both urban and rural sites (Stevens 2000; Perkins \& Attolini 1992; Mariotti Lippi et al. 2002; Bowes et al. 2015; Malone et al. 2014). Another expansion of tree crops, related to chestnut, is known historically in the more upland parts of Tyrrhenian Italy during the Medieval period. The peaks in pastoral indicators that occurred at 5000 and $2500 \mathrm{Cal}$ yr BP in the later Neolithic and mid Etruscan periods respectively, were more episodic and more difficult to compare with the archaeological record. However, some Late Neolithic and early Chalcolithic communities have been associated with an increase in mobility and pastoralism and the vegetational record may support this interpretation. There has been much discussion in the archaeological literature over the chronological depth of transhumance (Barker 2005) beyond the clear historical evidence from the medieval period. It is difficult to contribute in detail to this debate from the evidence presented here. However, we can note that by the late Bronze Age (c. 3000 BP), the dominance of ovicaprids had become a long-term trend which only became more balanced with cattle and pig in the full urban period (De Grossi Mazzorin 2006). The vegetational change in the mid Etruscan period may thus relate to a new relationship between city and countryside, where, for a short period, extensive stock raising became more important. The short-lived expansion of pastoral activity shown by the pollen may thus suggest a multi-facetted approach to agricultural intensification at the peak of Etruscan power in the middle of the third millennium BP (Supplemental material 2: Table S6).

In the later periods, the pastoralism appears to have expanded and this is matched by historical and ethnographic studies of transhumance in historical times (Barker 1989). More generally, at a broader scale, archaeo-demographic data show clear boom-and-bust cycles. There seem to have been two main long cycles ( 6000-4000 and 3500-1500 Cal yr BP) prior to Medieval times, presumably followed by a third cycle in the last 1200 years, for which archaeo-demographic data are not available, because of the nature of the field survey evidence, but which can be noted in the documentary records (e.g. Wickham 1988). A fourth boom has taken place in lowland areas in the post war period. Within the regional synthesis of records from Italy, there are no clear patterns evident between the average palaeoclimate z-scores, pollen-inferred vegetation change and the archaeo-demographic trends (Fig. 5). However, the amalgamation of datasets across the region leads to loss of information related to sub-regional climatic trends. Records from the north of Italy suggest that conditions became drier during the last 4000 years (Finné et al. this volume; see also discussion above). This coincides with periods of population expansion and increased agricultural activity, and suggests agricultural practices may have persisted throughout phases of drier climatic conditions. However, the complexity of interactions between human activity and natural environmental changes are highlighted within studies from individual sites located in Italy (e.g. Allen et al. 2002) and other studies highlight climate as having important impacts on vegetation change (e.g. Finsinger et al. 2010).

The most striking general regional trends relate to woodland. The cluster group 'fir forest', which represents an Abies-dominated mixed woodland, declined at $9000 \mathrm{Cal}$ yr BP, except at altitude, 
perhaps driven by data drawn from the pollen and charcoal records at Massaciuccoli and Accesa in northern Tyrrhenian Italy. The results are also supported by simulation approaches (Tinner et al. 2013, Henne et al. 2015) where slash and burn probably took place. The pollen-derived cluster groups comprise combinations of taxa that may represent opening of the landscape in response to human disturbance. Although beech woods are not well represented in Fig. 4, Fagus (beech) is also represented in other cluster groups. Fagus has a median value of $>30 \%$ in cluster 8.3 (beech woods) but is also represented in cluster 7.0 (fir forest) with a median of $6 \%$ and cluster 8.1 (alder woods) with a median of $3 \%$. Furthermore, the pasture/wetland cluster (3.0) is actually dominated by sedge (Cyperaceae) and although parkland/grassland (1.4) has a median value $>30 \%$ for Poaceae, this is accompanied by evergreen Quercus (8\%) and other minor taxa. Deciduous oak woodlands dominated the early record until 7500-7000 Cal yr BP when they were replaced by a more open landscape that retains some oaks as well as an increase in Alnus. These changes may be connected with the start of farming that led to the increase in oak parkland and also represents woody-steppe vegetation, which after $6700 \mathrm{BP}$ was potentially related to woodland management by early farming communities (cf. Supplemental Material 2: Table S1). Pine woods only occur very late in the record and intermittently earlier (represented by clusters 8.2 (coniferous forest) and 4.0 (pine forest)). Alder wood communities (based on Alnus Incana) increased in prominence from 7000 Cal yr BP and are known to respond positively to disturbances (Colombaroli et al. 2007). Non deciduous oak arboreal communities were more episodic, appearing and disappearing in frequency in the pollen record.

\section{Comparative Pollen Site Analysis}

Plots of individual pollen records (Figs. 6 and 7) demonstrate which sites are driving key changes in the region synthesis plots (Figs. 4 and 5), such as the early part of Massaciuccoli, which shows the presence of fir forest, while the API represents natural landscapes in the early part of some records, such as Lago dell'Accesa. In the Massaciuccoli area (Colombaroli et al. 2007; Mariotti Lippi et al. 2007a; Bellini et al. 2009) in the lower Arno valley, near the Etruscan site of S. Rocchino (Massarossa), wetlands were present in the valley bottom and on the coast (shown by hydrophilous species), and the current open landscape on the hillslopes (with dominance of low maquis or garrigue, i.e. Phillyrea, Erica sp., Juniperus) was only established in the Roman period, even if anthropogenic fire disturbance is recorded as early as $6000 \mathrm{Cal} \mathrm{yr} \mathrm{BP.} \mathrm{In} \mathrm{the} \mathrm{Accesa} \mathrm{area} \mathrm{(Drescher-}$ Schneider et al. 2007), some slight clearance was noticed as early as the Mesolithic ( $8900 \mathrm{Cal}$ yr BP), followed by a more notable clearance in the early and Middle Neolithic ( 8000-6600 Cal yr BP), with replacement of the former evergreen oak vegetation by deciduous oak forest and open shrublands (Colombaroli et al. 2008; 2009, Vanniere et al. 2008,) following slash and burn activities. The impact in the subsequent Bronze Age appears to have been reduced. The amount of open land does not appear to change drastically during the Etruscan period, and it was only with the foundation of a settlement near to Accesa in $\sim 2550$ Cal yr BP that a clearing can be interpreted locally. At Lago di Mezzano (not shown in Figs 6 and 7), a first anthropogenic clearance phase occurred during Bronze Age times (3700-3000 Cal yr BP), followed by woodland regeneration, with more permanent forest clearance and cultivation of tree crops only during Medieval and postMedieval times (Sadori 2018). This pattern appears to reflect local as much as regional land cover changes, as confirmed by the presence of archaeological sites and finds inside the lake at a time when its water level was lower than today. None the less, other inland sites, such as Lago Lungo 
(Mensing et al. 2015) also highlight the importance of the early Medieval period in human land cover transformation away from the coast.

The southern Latial lakes of Albano and Nemi appear to show major changes in human-caused vegetation shifts (Mercuri et al. 2002) and cereals that start with the Neolithic (c. 7000 Cal yr BP), register a new increase from $\sim 3000 \mathrm{Cal} y r \mathrm{BP}$ with the introduction of tree crops and show the highest impact in the early Roman period, although there are earlier noticeable effects and fluctuations. These lakes were relatively close to urban centres such as Tusculum, Alba Longa and Gabii. The record from Lake Vico in South Etruria appears only to show appreciable woodland clearance and cereals from about 2.6 ka BP (Magri \& Sadori 1999), perhaps responding to its more marginal location with respect to settlement and greater protection from the surrounding agricultural landscape. However, this is not detected in the pollen-inferred vegetation clusters, which highlights the importance of understanding site level characteristics. The record from the Lake Lagaccione shows some clearance at about 3.7 ka BP (Magri 1999) but is unfortunately truncated in its upper part when the area might have been influenced by the development of the relatively short lived urban centre of Bisenzio (Babbi 2016). Stracciacappa is unfortunately another truncated sequence that offers no information after $7200 \mathrm{Cal}$ yr BP when it was still heavily wooded (Giardini 2007). Fortunately, Lago di Mezzano is located close to Lagaccione and extends the pollen record up to modern times (Sadori 2018). The pollen record from Stagno di Maccarese (Di Rita et al. 2010; 2015) shows a clear human impact on the landscape, documented by a peak of micro-charcoal concentrations and cereal-type pollen, contemporary with the nearby middle Chalcolithic settlement of Le Cerquete-Fianello, dated between 5.4 and 4.9 ka BP. After a period of human abandonment of the area, an increase around $2.6 \mathrm{ka}$ BP in pollen of the Chenopodiaceae family that contains species adapted to growing in saline environments marks the usage of the basin as salt works by the local Etruscan populations. After $2.4 \mathrm{ka} \mathrm{BP}$, when the Romans took control of the salt works, and especially in Imperial time, signs of human activities are documented by high values of API and OJCV.

\section{Conclusions}

The current paper corroborates some interpretations and challenges others. The impact of the classical period (Etruscan and early to early imperial Roman) on the human and natural landscape has been both confirmed and given extra nuance. The Etruscan impact on the landscape was noteworthy, but highly varied, both between South and North Etruria and in the vicinity of known sites. The Roman impact was more pervasive. On the other hand, the apparently low level of activity in the Neolithic and Bronze Age from purely archaeological evidence may need to be challenged by the vegetational evidence, as changes can be noted in woodland composition and density, as well as in the SPD data, that were not apparent from the site counts.

This analysis of Tyrrhenian central Italy exhibits some general trends that appear to combine human and climatic effects: on the one hand a warm climatic period in Roman times was preceded in the third millennium BP and succeeded in the first and second millennia BP by periods of cooler climate (according to Benvenuti et al. 2006 and Büntgen et al. 2016), and there is further evidence of drier conditions from $5500 \mathrm{BP}$ (Marchetto et al. 2008); on the other hand, there was substantial local variation that would have been a response to the local intensification of human intervention, depending on the level of settlement size and urbanisation. Some river regimes persistently suffered from flood risk (Benvenuti et al. 2010; 2006). More open woodland increased over time, 
starting in the Neolithic, which may initially have largely taken the form of small clearings often in well-watered locations such as San Marco (Valley of Gubbio) and La Marmotta (Lago di Bracciano). Pastoralism was probably an increasing feature of the Late Neolithic and Early Bronze Age, although the degree of long distance transhumance cannot be assessed from the data presented here.

Urbanisation would have led to more intensive exploitation of the landscape, but, in its initial stages, this would have encompassed considerable local variation, both at a regional scale (less developed North Etruria vs intensive South Etruria vs intensive Latium vetus), and between individual cities as shown by the variation in the relationship between the urban centre and the degree of rural settlement (Stoddart 2016). Tree crops accompanied the establishment of the first larger towns or cities after $3000 \mathrm{Cal}$ yr BP, when, for the first time, fixed food resources tied to the land could have been more easily protected. As already emphasised, these broad trends conceal substantial local differences. In northern Tyrrhenian Italy, in the context of less developed rural settlement, the open landscape was probably only established in the Roman period. In the southern Tyrrhenian region, in the context of long-established and intense urbanism, the impact on the local landscape was felt much earlier, in the third millennium BP. In the Roman period, many of these effects would have become more generalised, declined with the reduction of political power in late antiquity, and then revived with the rise of the independent city states of the Medieval and Renaissance period. We know from other evidence not considered here that the uplands have been extensively abandoned in the late modern period, but the lowlands have recently been intensely farmed, in response to the political economy of the European Union.

Acknowledgements

This work is the result of a workshop held in Mallorca in September 2017 under the auspices of the Leverhulme Trust funded project "Changing the Face of the Mediterranean: Land Cover and Population Since the Advent of Farming" (Grant Ref. RPG-2015-031), a Plymouth-UCL collaboration. We are grateful to Joan Estrany and the University of the Balearic Islands for helping to host this workshop. Pollen data were extracted from the European Pollen Database (EPD; http://www.europeanpollendatabase.net/) and amalgamated from the work of data contributors. The EPD community is gratefully acknowledged and gratitude is given to Michelle Leydet (the EPD manager), and many data contributors who have made a valuable contribution to this research.

Data

Archaeological data sets used in this work for modelling demographic trends can be found in the journal data paper by Palmisano et al. (2018) and UCL Discovery online repository: https://doi.org/10.14324/000.ds.1575442

\section{References}

Alessandri, L., 2016. Hierarchical and federative polities in protohistoric Latium Vetus. An analysis of Bronze Age and Early Iron Age settlement organization. In: P. Attema, J. Seubers, and S. Willemsen (eds.), Early states, territories and settlements in protohistoric Central Italy. Corollaria Crustumina 2. Groningen: Groningen Institute of Archaeology 
Allen, J.R.M, Watts, W.A, McGee, E. \& Huntley, B (2002) Holocene environmental variability-the record from Lago Grande di Monticchio, Italy. Quaternary International: 88, 69-80.

Arnoldus Huyzendveld, A., Bietti Sestieri, A. M., De Rossi, G., Foschi, A., Giacobbe, M., Giacopini, L., Mantero, D., Nonnis, D., Panu, B. E., Preite, A., Sebastiani, R., Tomassetti, A. \& Ventrelli, M. 1993. L'area archeologica a Sud di Roma. (Comune di Roma, Assessorato alla Cultura, Centro di coordinamento didattico 63). Roma: Fratelli Palombi Editori.

Attema, P. 1993. An archaeological survey in the Pontine region. A contribution to the early settlement history of south Lazio 900 - 100 BC. Vol. I: Text. Groningen: Archeologisch Centrum Groningen.

Attema, P., Burgers, G.J. \& Leusen, M.V., 2010. Regional pathways to complexity: settlement and land-use dynamics in early Italy from the Bronze Age to the Republican period. Amsterdam: Amsterdam University Press.

Babbi, A. 2016. Bisenzio between proto-history and the archaic period: the Research Project. In Della Fina, G. M. (ed.) Dalla Capanna al Palazzo. Edilizia abitativa nell'Italia preromana. (Annali della Fondazione per il Museo «Claudio Faina» 24). Roma: Quasar, 169-86.

Barbaro, B. 2010. Insediamenti, aree funerari ed entita territoriali in Etruria meridionale nel Bronzo Finale. Firenze: All'Insegna del Giglio.

Barker, G. 1989. The archaeology of the Italian shepherd. Transactions of the Cambridge Philosophical Society 215: 1-19.

Barker, G. 2005. Agriculture, pastoralism and Mediterranean landscapes in prehistory. In Blake, E. \& Knapp, B. (eds.), The archaeology of Mediterrnean prehistory. Oxford: Blackwell, 46-76.

Barker, G. \& Rasmussen, T. 1988. The archaeology of an etruscan polis: a preliminary report on the Tuscania project. 1986 and 1987 seasons. Papers of the British School at Rome 56: 25-42.

Barker, G. \& Stoddart, S. K. F. 1994. The Bronze Age of Central Italy: c. 2000-900 BC. In Mathers, C. \& Stoddart, S. (eds.), Development and Decline in the Mediterranean Bronze Age. Sheffield: J.R. Collis Publications, 14566.

Becker, J. A., Mogetta, M. \& Terrenato, N. 2009. A new plan for an ancient Italian city: Gabii Revealed. American Journal of Archaeology 113 (4): 629-42.

Bellini, C., Mariotti Lippi, M., Mori Secci, M., Aranguren, B. \& Perazzi, P. 2008. Plant gathering and cultivation in prehistoric Tuscany (Italy). Vegetation History and Archaeobotany 17: 103-12.

Bellini, C., Mariotti Lippi, M. \& Montanari, C. 2009. The Holocene landscape history of the NW Italian coasts. The Holocene 19: 1161-72.

Benvenuti, M., Mariotti Lippi, M., Pallecchi, P. \& Sagri, M. 2006. Late-Holocene catastrophic floods in the terminal Arno River (Pisa, Central Italy) from the story of a Roman riverine harbour. The Holocene 16 (6): 863-76.

Benvenuti, M., Bellini, C., Censini, G., Mariotti Lippi, M., Pallecchi, P. \& Sagri, M. 2010. Floods, Mudflows, Landslides: Adaptation of Etruscan-Roman Communities to Hydrogeological Hazards in the Arno River Catchment (Tuscany, Central Italy). In Martini, I. P. \& Chesworth, W. (eds.), Landscapes and societies: selected cases. Dordrecht: Springer, 187-201.

Bertacchi, A. \& Onnis, A. 2004. Changes in the Forested Agricultural Landscape of the Pisan Hills (Tuscany, Italy). In Mazzoleni, S., Di Pasquale, G., Mulligan, M., Di Martino, P. \& Rego, F. (eds.), Recent Dynamics of the Mediterranean Vegetation and Landscape. Chichester: Wiley \& Sons Ltd, 167-78.

Bevan, A. \& Crema, E.R. 2018) rcarbon v1.2.0: Methods for calibrating and analysing radiocarbon dates. URL: https://CRAN.R-project.org/package=rcarbon 
Bevan, A., Colledge, S., Fuller, D., Fyfe, R., Shennan, S. \& Stevens, C., 2017. Holocene fluctuations in human population demonstrate repeated links to food production and climate. Proceedings of the National Academy of Sciences 114 (49), E10524-E10531.

Bietti Sestieri, A. M. 2010. L'Italia nell'età del bronzo e del ferro. Roma: Carocci editore.

Blaauw, M. \& Andrés Christen, J. 2011. Flexible Paleoclimate Age-Depth Models Using an Autoregressive Gamma Process. Bayesian Analysis 6 (3): 457-74.

Bowes, K., Mercuri, A. M., Rattighieri, E., Rinaldi, R., Arnoldus-Huyzendveld, A., Ghisleni, M., Grey, C., Mackinnon, M., \& Vaccaro, E. 2015. Palaeoenvironment and land use of Roman peasant farmhouses in southern Tuscany, Plant Biosystems 149: 174-184.

Büntgen U., Myglan V. S., Ljungqvist F.C. et al. 2016. Cooling and societal change during the Late Antique Little Ice Age from 536 to around 660 AD. Nature Geoscience 9, 231-36.

Campana, S. 2001. Murlo. Carta archeologica della Provincia di Siena. Vol. V. Siena: Nuova Immagine.

Camporeale, G. 1997. L'abitato etrusco dell'Accesa: il quartiere B. (Archaeologica 122). Roma: G. Bretschneider.

Carandini, A. \& Cambi, F. (eds.). 2002. Paesaggi d'Etruria: Valle dell'Albegna, Valle d'Oro, Valle del Chiarone, Valle del Tafone : progetto di ricerca italo-britannico seguito allo scavo di Settefinestre. Roma: Edizioni di storia e letteratura.

Colombaroli, D., Marchetto, A. \& Tinner, W. 2007. Long-term interactions between Mediterranean climate, vegetation and fire regime at Lago di Massaciuccoli (Tuscany, Italy). Journal of Ecology 95: 755-70.

Colombaroli, D., Vannière, B., Chapron, E., Magny, M. \& Willy, T. 2008. Fire vegetation interactions during the Mesolithic Neolithic transition at Lago dell'Accesa, Tuscany, Italy. The Holocene 18: 679-92.

Colombaroli, D., Tinner, W., Van Leeuwen, J., Noti, R., Vescovi, E., Vannière, B., Magny, M., Schmidt, R. \& Bugmann, H. 2009. Response of broadleaved evergreen Mediterranean forest vegetation to fire disturbance during the Holocene: Insights from the peri-Adriatic region. Journal of Biogeography 36, (2): 314-26.

Crema, E. R., Bevan, A., \& Lake, M., 2010. A probabilistic framework for assessing spatio-temporal point patterns in the archaeological record. Journal of Archaeological Science 37, 1118-1130.

Crema, E.R., 2012. Modelling temporal uncertainty in archaeological analysis. Journal of Archaeological Method and Theory 19(3), 440-461.

Crema, E.R., \& Bevan, A., 2018. rcarbon v1.1.2 : Methods for calibrating and analysing radiocarbon dates URL: https://CRAN.R-project.org/package=rcarbon

Cremaschi, M., Mercuri, A. M., Torri, P., Florenzano, A., Pizzi, C., Marchesini, M., \& Zerboni, A. 2016. Climate change versus land management in the Po Plain (Northern Italy) during the Bronze Age: new insights from the VP/VG sequence of the Terramara Santa Rosa di Poviglio. Quaternary Science Reviews 136: 153-172.

Cucini, C. 1985. Topografia del territorio delle valli del Pecora e dell'Alma. In Francovich, R. (ed.) Scarlino I. Storia e territorio. Firenze: All'Insegna del Giglio, 147-320.

Davis, B. A. S., Zanon, M., Collins, P., Mauri, A., Bakker, J., Barboni, D., Barthelmes, A., Beaudouin, C., Bjune, A. E., Bozilova, E., Bradshaw, R. H. W., Brayshay, B. A., Brewer, S., Brugiapaglia, E., Bunting, J., Connor, S. E., de Beaulieu, J.-L., Edwards, K., Ejarque, A., Fall, P., Florenzano, A., Fyfe, R., Galop, D., Giardini, M., Giesecke, T., Grant, M. J., Guiot, J. e., Jahns, S., Jankovska, V., Juggins, S., Kahrmann, M., Karpinska-Kołaczek, M., Kołaczek, P., Kühl, N., Kunes, P., Lapteva, E. G., Leroy, S. A. G., Leydet, M., Guiot, J., Jahns, S., Jankovska, V., Juggins, S., Kahrmann, M., Karpińska-Kołaczek, M., Kołaczek, P., Kühl, N., Kunes, P., Lapteva, E., Leroy, S. A. G., Leydet, M., López Sáez, J. A., Masi, A., Matthias, I., Mazier, F., Meltsov, V., Mercuri, A. M., Miras, Y., Mitchell, F. J. G., Morris, J. L., Naughton, F., Nielsen, A. B., Novenko, E., Odgaard, B., Ortu, E., Overballe- 
De Grossi Mazzorin, J. 2006. Il quadro attuale delle ricerche archeozoologiche in Etruria e nuove prospettive di ricerca. In Curci, A., Vitali, D. \& Penzo, A. (eds.), Animali tra uomini e dei: archeozoologia del mondo preromano: atti del convegno internazionale, 8-9 novembre 2002. Bologna: Ante quem, 77-96.

di Gennaro, F. \& Stoddart, S. K. F. 1982. A review of the evidence for prehistoric activity in part of South Etruria. Papers of the British School at Rome 50: 1-21.

Di Rita, F., Celant, A. \& Magri, D. 2010. Holocene environmental instability in the wetland north of the Tiber delta (Rome, Italy): sea-lake-man interactions. Journal of Paleolimnology 44: 51-67.

Di Rita, F., Celant, A., Milli, S. \& Magri, D. 2015. Lateglacial-early Holocene vegetation history of the Tiber delta (Rome, Italy) under the influence of climate change and sea level rise. Review of Palaeobotany and Palynology 218: 204-16.

Di Rita, F., Fletcher, W. J., Aranbarri, J., Margaritelli, G., Lirer, F. \& Magri, D. 2018. Holocene forest dynamics in central and western Mediterranean: periodicity, spatio-temporal patterns and climate influence. Scientific Reports 8: 8929. https://doi.org/10.1038/s41598-018-27056-2.

Drennan, R. D., Berrey, C. A. \& Peterson, C. E. 2015. Regional settlement demography in archaeology. Clinton Corners, New York: Eliot Werner Publications, Inc.

Drescher-Schneider, R., de Beaulieu, J.-L., Magny, M., Walter-Simonnet, A., Bossuet, G., Millet, L., Brugiapaglia, E. \& Drescher, A. 2007. Vegetation history, climate and human impact over the last 15,000 years at Lago dell'Accesa (Tuscany, central Italy). Vegetation History and Archaeobotany 16: 279-99.

Drysdale, R., Zanchetta, G., Hellstrom, J., Maas, R., Fallick, A., Pickett, M., Cartwright, I. \& Piccini, L. 2006. Late Holocene drought responsible for the collapse of Old World civilizations is recorded in an Italian cave flowstone. Geology 34: 101-4.

Enei, F. 2001. Progetto Ager Caerentanus. Il littorale di Alsium. (Ricognizioni archeologiche nel territorio di Ladispoli, Cerveteri e Fiumicino). Ladispoli: Comune di Ladispoli - Regione Lazio.

Finsinger, W., Colombaroli, D., De Beaulieu, J.-L., Valsecchi, V., Vannière, B., Vescovi, E., Chapron, E., Lotter, A. F., Magny, M. \& Tinner, W. 2010. Early to mid-Holocene climate change at Lago dell'Accesa (central italy): climate signal or anthropogenic bias? Journal of Quaternary Science 25 (8): 1239-47.

Fornaciari, G. 1978. Il Villaggio di S. Rocchino presso Viareggio. Storia di un insediamento costiero Ligure-Etrusco. Rivista dell'Artiglio 4: 1-3 (?).

French, C., Farrell, M., Hunt, C., Malone, C., Schembri, P. J., McLaughlin, R, Stoddart, S. \& Vella, N. (eds.). in preparation. Environment and human landscape of the Maltese islands 6500 BC - 2100 AD. Cambridge: McDonald Institute.

Fugazzola Delpino, M. A., d'Eugenio, G. \& Pessina, A. 1993. La Marmotta (Anguillara Sabazia, Roma): un abitato perilacustre di età neolitica. Bullettino di Paletnologia italiana 84 (n.s. 1): 181-341.

Fulminante, F. 2014. The urbanisation of Rome and Latium Vetus. From the Bronze Age to the Archaic Era. Cambridge: Cambridge University Press.

Fyfe, R. M., Woodbridge, J. \& Roberts, N. 2018. Trajectories of change in Mediterranean Holocene vegetation through classification of pollen data. Vegetation History and Archaeobotany 27: 351-64. 
Galate, P. 2011. BANADORA. Banque de données des dates radiocarbones de Lyon pour l'Europe et le Proche-Orient. Université Claude Bernard, Lyon: [Internet] http://www.archeometrie.mom.fr/banadora/.

Giachi, G., Mori Secci, M., Pignatelli, O., Gambogi, P. \& Mariotti Lippi, M. 2010. The prehistoric pile-dwelling settlement of Stagno (Leghorn, Italy): wood and food resource exploitation. Journal of Archaeological Science 37: 1260-8.

Giardini, M. 2007. Late Quaternary vegetation history at Stracciacappa (Rome, central Italy). Vegetation History and Archaeobotany 16: 301-16.

Giesecke, T., Davis, B., Brewer, S., Finsinger, W., Wolters, S., Blaauw, M., de Beaulieu, J.-L., Binney, H., Fyfe, R. M., Gaillard, M.-J., Gil-Romera, G., van der Knaap, W. O., Kunes, P., Kühl, N., van Leeuwen, J. F. N., Leydet, M., Lotter, A. F., Ortu, E., Semmler, M. \& Bradshaw, R. H. W. 2013. Towards mapping the late Quaternary vegetation change of Europe. Vegetation History and Archaeobotany 23: 75-86.

Grove, A. T. \& Rackham, O. 2001. The nature of Mediterranean Europe: an ecological history. New Haven: Yale University Press.

Guaitoli, M. 1982. Gabii. Osservazioni sulle fasi di sviluppo dell'abitato. Quaderni dell'stituto di Topografia antica dell'Università di Roma 9: 23-57.

Guidi, A., \& Piperno, 1993. Italia preistorica. Bari: Laterza

Henne, P. D., Elkin, C., Franke, J., Colombaroli, D., Caló, C., La Mantia, T., Pasta, S., Conedera, M., Dermody, O. \& Tinner, W. 2015. Reviving extinct Mediterranean forest communities may improve ecosystem potential in a warmer future. Frontiers in Ecology and the Environment 13 (7): 356-62.

Koláŕ, J., Macek, M., Tkáč, P. \& Szabó, P., 2016. Spatio-Temporal Modelling As A Way to Reconstruct Patterns of Past Human Activities. Archaeometry 58(3), 513-528.

Hamilton, W. D., Haselgrove, C. \& Gosden, C. 2015. The impact of Bayesian chronologies on the British Iron Age. World Archaeology 47 (4): 642-60.

Juggins, S. 2015. 'Rioja': Analysis of Quaternary Science Data, R package version (0.9-9). (http://cran.rproject.org/package=rioja).

Kelly, R. L. 2013. The lifeways of hunter-gatherers: the foraging spectrum. Cambridge: Cambridge University Press.

Leydet, M. 2007-2017. The European Pollen Database. (online: http://www.europeanpollendatabase.net/). Accessed: Oct. 2017.

Magri, D. 1999. Late-Quaternary vegetation history at Lagaccione near Lago di Bolsena (central Italy). Review of Palaeobotany and Palynology 106: 171-208.

Magri, D., Agrillo, E., Di Rita, F., Furlanetto, G., Pini, R., Ravazzi, C. \& Spada, F. 2015. Holocene dynamics of tree taxa populations in Italy. Review of Palaeobotany and Palynology 218: 267-84.

Magny, M., Peyron, O., Sadori, L., Ortu, E., Zanchetta, G., Vannière, B. \& Tinner, W. 2012. Contrasting patterns of precipitation seasonality during the Holocene in the south- and north-central Mediterranean. Journal of Quaternary Science 27 (3): 290-6.

Magny, M., Combourieu-Nebout, N., de Beaulieu, J. L., Bout-Roumazeilles, V., Colombaroli, D., Desprat, S., Francke, A., Joannin, S., Ortu, E., Peyron, O., Revel, M., Sadori, L., Siani, G., Sicre, M. A., Samartin, S., Simonneau, A., Tinner, W., Vannière, B., Wagner, B., Zanchetta, G., Anselmetti, F., Brugiapaglia, E., Chapron, E., Debret, M., Desmet, M., Didier, J., Essallami, L., Galop, D., Gilli, A., Haas, J. N., Kallel, N., Millet, L., Stock, A., Turon, J. L. \& Wirth, S. 2013. North-south palaeohydrological contrasts in the central Mediterranean during the Holocene: tentative synthesis and working hypotheses. Climate of the Past 9 (5): 2043-71. 
Malone, C. 2003. The Italian Neolithic: a synthesis of research. Journal of World Prehistory 17 (3): 235-312.

Malone, C., Stoddart, S., Barker, G., Coltorti, M., Costantini, L., Giorgi, J., Clark, G., Harding, J., Hunt, C., Reynolds, T. \& Skeates, R. 1992. The Neolithic site of San Marco, Gubbio (Perugia), Umbria: survey and excavation, 1985-7. Papers of the British School at Rome 60: 1-69.

Malone, C., Stoddart, S., Ceccarelli, L., Cenciaioli, L., Duff, P., McCormick, F., Morales, J., Armstrong, S., Bates, J., Bennett, J., Cameron, J., Cifani, G., Cohen, S., Foley, T., Fulminante, F., Hill, H., Mattacchoni, L., Neil, S., Rosatelli, A., Redhouse, D. \& Volhard-Dearman, S. 2014. Beyond feasting: consumption and life style amongst the invisible Etruscans. In Boyle, K., Rabett, R. \& Hunt, C. (eds.), Living in the Landscape. Essays in honour of Graeme Barker. Cambridge: McDonald Institute, 257-66.

Manning, K., Timpson, A., College, S., Crema, E. \& Shennan, S. 2015. The cultural evolution of Neolithic Europe. EUROEVOL dataset. Available at: http://discovery.ucl.ac.uk/1469811/ (accessed 01/05/2018).

Marchetto, A., Colombaroli, D. \& Tinner, W. 2008. Diatom response to mid-Holocene climate change in Lago di Massaciuccoli (Tuscany, Italy). Journal of Paleolimnology 40 (1): 235-45.

Mariotti Lippi, M., Giachi, G., Paci, S. \& Di Tommaso, P. L. 2000. Studi sulla vegetazione attuale e passata della Toscanameridionale (Follonica - Italia) e considerazioni sull'impatto ambientale dell'attività metallurgica etrusca nel VI-V secolo a.C. Webbia 55 (2): 279-95.

Mariotti Lippi, M., Di Tommaso, P. L., Giachi, G., Mori Secci, M. \& Paci, S. 2002. Archeo-botanical investigations into an etruscan farmhouse at Pian d'Alma (Grosseto, Italy). Atti della Società Toscana di Scienze Naturali (Serie B) 109: 159-65.

Mariotti Lippi, M., Guido, M., Menozzi, B. I., Bellini, C. \& Montanari, C. 2007a. The Massaciuccoli Holocene pollen sequence and the vegetation history of the coastal plains by the Mar Ligure (Tuscany and Liguria, Italy). Vegetation History and Archaeobotany 16: 267-77.

Mariotti Lippi, M., Bellini, C., Trinci, C., Benvenuti, M., Pallecchi, P. \& Sagri, M. 2007b. Pollen analysis of the ship site of Pisa San Rossore, Tuscany, Italy: the implications for catastrophic hydrological events and climatic change during the late Holocene. Vegetation History and Archaeobotany 16: 453-65.

Mayewski, P. A., Rohling, E. E., Stager, J. C., Karlén, W., Maasch, K. A., Meeker, L. D., Meyerson, E. A., Gasse, F., van Kreveld, S., Holmgren, K., Lee-Thorp, J., Rosqvist, G., Rack, F., I Staubwasser, M., Schneider, R. R. \& Steig, E. J. 2004. Holocene climate variability. Quaternary Research 62: 243-55.

Mazier, F., Galop, D., Brun, C. \& Buttler, A. 2006. Modern pollen assemblages from grazed vegetation in the western Pyrenees, France: a numerical tool for more precise reconstruction of past cultural landscapes. Holocene 16: 91-103.

Mensing, S.A., Tunno, I., Sagnotti, L., Florindo, F., Noble, P., Archer, C. et al. 2015. 2700 years of Mediterranean environmental change in central Italy: a synthesis of sedimentary and cultural records to interpret past impacts of climate on society. Quaternary Science Reviews 116: 72-94:

Mercuri, A. M., Bandini Mazzanti, M., Florenzano, A., Montecchi, M. C. \& Rattighieri, E. 2013a. Olea, Juglans and Castanea: The OJC group as pollen evidence of the development of human-induced environments in the Italian peninsula. Quaternary International 303: 24-42.

Mercuri, A. M., Bandini Mazzanti, M., Florenzano, A., Montecchi, M. C., Rattighieri, E. \& Torri, P. 2013 b. Anthropogenic pollen indicators (API) from archaeological sites as local evidence of human-induced environments in the italian peninsula. Annali di Botanica 3: 143-53.

Mercuri, A. M., Accorsi, C. A. \& Bandini Mazzanti, M. 2002. The long history of Cannabis and its cultivation by the Romans in central Italy, shown by pollen records from Lago Albano and Lago di Nemi. Vegetation History and Archaeobotany 11: 263-76. 
Minniti, C. 2012. Ambiente, Sussistenza e articolazione sociale nell' Italia Centrale tra Bronzo Medio e Primo Ferro (British Archaeological Reports International Series 2394). Oxford: Archaeopress.

Morris, E. K., Caruso, T., Buscot, F., Fischer, M., Hancock, C., Maier, T. S., Meiners, T., Müller, C., Obermaier, E., Prati, D., Socher, S. A., Sonnemann, I., Wäschke, N., Wubet, T., Wurst, S. \& Rillig, M. C. 2014. Choosing and using diversity indices: insights for ecological applications from the German Biodiversity Exploratories. Ecology and Evolution 4: 3514-24.

Morselli, C. \& Tortorici, E. 1982. Ardea, Forma Italiae, Regio I- Volumen XVI. Firenze: Leo S. Olschki.

Naso, A. 2000. The Etruscan aristocracy in the Orientalizing period: Culture, Economy, relations. In Torelli, M. (ed.) The Etruscans. Milan: Bompiani, 111-29.

Oksanen, J., Blanchet, F. G., Friendly, M., Kindt, R., Legendre, P., McGlinn, D., Minchin, P. R., O'Hara, R. B., Simpson, G. L., Solymos, P., Stevens, M. H. H., Szoecs, E. \& Wagne, H. 2016. 'Vegan': Community Ecology Package. $R$ package version $2.4-1$.

ORAU 2016. Oxford Radiocarbon Accelerator Unit (ORAU) database. Available at: https://c14.arch.ox.ac.uk/.

Orton, D., Morris, J. \& Pipe, A., 2017. Catch Per Unit Research Effort: Sampling Intensity, Chronological Uncertainty, and the Onset of Marine Fish Consumption in Historic London. Open Quaternary, 3(1), 1-20.

Pacciarelli, M. 2000. Dal villaggio alla città: la svolta protourbana del 1000 a.C. nell'Italia tirrenica. (Grandi contesti e problemi della protostoria italiana 4). Firenze: All'insegna del Giglio.

Palmisano, A., Bevan, A. \& Shennan, S., 2017. Comparing archaeological proxies for long-term population patterns: An example from central Italy. Journal of Archaeological Science 87, 59-72.

Palmisano, A., Bevan, A. \& Shennan, S., 2018. Regional Demographic Trends and Settlement Patterns in Central Italy: Archaeological Sites and Radiocarbon Dates. Journal of Open Archaeology Data. 6(1), p.2. DOI: http://doi.org/10.5334/joad.43

Patterson, H., Di Giuseppe, H. \& Witcher, R. 2004. Three South Etruria 'Crises': First results of the Tiber Valley Project. Papers of the British School at Rome 72: 1-36.

Perkins, P. \& Attolini, I. 1992. An Etruscan farm at Podere Tartuchino. Papers of the British School at Rome 60: 71134.

Peroni, R., Carancini, G. L., Bergonzi, G., Lo Schiavo, F. \& Von Eles, P. 1980. Per una definizione critica di facies locali: nuovi strumenti metodologici. In Peroni, R. (ed.) /l Bronzo Finale in Italia. Bari: De Donato, 9-87.

Peyron, O., Combourieu-Nebout, N., Brayshaw, D., Goring, S., Andrieu-Ponel, V., Desprat, S., Fletcher, W., Gambin, B., Ioakim, C., Joannin, S., Kotthoff, U., Kouli, K., Montade, V., Pross, J., Sadori, L. \& Magny, M. 2017. Precipitation changes in the Mediterranean basin during the Holocene from terrestrial and marine pollen records: a model-data comparison. Climate of the Past 13 (3): 249-65.

Radi, G. \& Petrinelli Pannocchia, C. 2018. The beginning of the Neolithic era in Central Italy. Quaternary International. 470: 270-84.

Rajala, U., 2013. The concentration and centralization of late prehistoric settlement in central Italy: the evidence from the Nepi Survey. Papers of the British School at Rome 81, 1-38.

Reimer, P. J., Bard, E., Bayliss, A., Beck, J. W., Blackwell, P. G., Bronk Ramsey, C., Buck, C. E., Cheng, H., Edwards, R. L., Friedrich, M., Grootes, P. M., Guilderson, T. P., Haflidason, H., Hajdas, I., Hatté, C., Heaton, T. J., Hoffmann, D. L., Hogg, A. G., Hughen, K. A., Kaiser, K. F., Kromer, B., Manning, S. W., Niu, M., Reimer, R. W., Richards, D. A., Scott, E. M., Southon, J. R., Staff, R. A., Turney, C. S. M. \& van der Plicht, J. 2013. IntCal13 and Marine13 radiocarbon age calibration curves 0-50,000 Years cal BP. Radiocarbon 55 (4): 1869-87. 
Ridgway, D. \& Ridgway, F., R (eds.) 1979. Italy before the Romans. The Iron age, Orientalizing and Etruscan periods. London: Academic Press.

Roberts, N., Brayshaw, D., Kuzucuoğlu, C., Perez, R. and Sadori, L. 2011. The mid-Holocene climatic transition in the Mediterranean: causes and consequences. The Holocene 21, 3-13.

Roberts, N., Woodbridge, J., Bevan, A., Palmisano, A., Shennan, S. \& Asouti, E., 2017. Human responses and nonresponses to climatic variations during the last glacial-interglacial transition in the eastern Mediterranean. Quaternary Science Reviews 184, 47-67.

Sadori, L. 2018 The Lateglacial and Holocene vegetation and climate history of Lago di Mezzano (central Italy). Quaternary Science Reviews 202, 30-44

Shennan, S., Downey, S. S., Timpson, A., Edinborough, K., Colledge, S., Kerig, T., Manning, K. \& Thomas, M. G. 2013. Regional population collapse followed initial agriculture booms in mid-Holocene Europe. Nature Communications: DOI: 10.1038/ncomms3486.

Simpson, E. H. 1949. Measurement of diversity. Nature: 163: 688.

Skeates, R. 1994. Towards an absolute chronology for the Neolithic in central Italy. In Skeates, R. \& Whitehouse, R. (eds.), Radiocarbon Dating and Italian Prehistory. London: British School at Rome - Accordia Research Centre, 61-72.

Stevens, C. 2000. Plant remains. Papers of the British School at Rome 67: 330-3.

Stoddart, S. 1999. Beyond historical demography: the contribution of archaeological survey. In Bintliff, J. \& Sbonias, K. (eds.), Reconstructing Past population trends in Mediterranean Europe. Oxford: Oxbow, 12931.

Stoddart, S. 2016. Power and Place in Etruria. In Manuel Fernández-Götz, M. \& Krausse, D. (eds.), Eurasia at the Dawn of History: Urbanization and Social Change. Cambridge: Cambridge University Press, 304-18.

Stoddart, S. in press. Power and Place in Etruria. The spatial dynamics of a Mediterranean civilisation. 1200-500 B.C. Cambridge: Cambridge University Press.

Terrenato, N. 1996. Visibility and Site Recovery in the Cecina Valley Survey, Italy. Journal of Field Archaeology 23 . 91-109.

Timpson, A., Colledge, S., Crema, E., Edinborough, K., Kerig, T., Manning, K., Thomas, M.G. and Shennan, S., 2014. Reconstructing regional population fluctuations in the European Neolithic using radiocarbon dates: a new case-study using an improved method. Journal of Archaeological Science 52, 549-557.

Tinner, W., Colombaroli, D., Heiri, O., Henne, P. D., Steinacher, M., Untenecker, J., Vescovi, E., Allen, J. R. M., Carraro, G., Conedera, M., Joos, F., Lotter, A. F., Luterbacher, J., Samartin, S. \& Valsecchi, V. 2013. The past ecology of Abies alba provides new perspectives on future responses of silver fir forests to global warming. Ecological Monographs 83 (4): 419-39.

Turchin, P. 2001. Does population ecology have general laws? Oikos 94 (1): 17-26.

Ward, J. H. 1963. Hierarchical grouping to optimize an objective function. Journal of the American Statistical Association 58: 236-44.

Watson, C. S. 1996. The vegetational history of the northern Apennines, Italy: information from three new sequences and a review of Regional vegetational change. Journal of Biogeography 23 (6): 805-41.

Weninger, B., Clare, L., Jöris, O., Jung, R. \& Edinborough, K., 2015. Quantum theory of radiocarbon calibration. World Archaeology, 47(4), 543-566. 
Williams, A.N., 2012. The use of summed radiocarbon probability distributions in archaeology: a review of methods. Journal of Archaeological Science, 39(3), 578-589.

Wickham, C. 1988. The mountains and the city. The Tuscan Appennines in the early Middle Ages. Oxford: Clarendon 'Press.

Woodbridge J., Roberts, N. \& Fyfe, R. (in review) Pan-Mediterranean Holocene vegetation and land-cover dynamics from synthesised pollen data. Journal of Biogeography.

Figures

Fig. 1. Map showing the a) distribution of archaeological radiocarbon samples and b) archaeological sites and pollen archive sites (the yellow polygons indicate the boundary of the archaeological surveys).

Fig. 2. Summed Probability Distribution (SPD) of unnormalised calibrated radiocarbon dates (solid line) vs. a fitted logistic model (95\% Monte-Carlo confidence grey envelope) of population growth.

Fig. 3. a) Comparison of raw site count (solid line), summed settlement areas (red line), aoristic sum (dashed line), and randomised site start dates (grey envelope) from 10 to 1.5. ka BP; b) Inset of population change between 10 and $2.8 \mathrm{ka}$ BP.

Fig. 4 Pollen-inferred vegetation cluster groups (11,000 BP - modern) for Tyrrhenian central Italy compared with proxy archaeological data.

Fig. 5 Pollen indicator groups: arboreal pollen (\%AP), sum of Olea, Juglans, Castanea and Vitis (O/OJC/OJCV), anthropogenic pollen index (API), and pastoral indicators averaged for all sites in the study area (11,000 BP to modern) compared with proxy archaeological data. Regional average zscores are presented for 14 palaeoclimate records from across Italy (for further information about the palaeoclimate datasets see Finné et al., this volume).

Fig. 6 Arboreal Pollen \% (AP\%) plotted in the x-axis for each pollen site plotted with cluster analysis derived vegetation cluster (symbols) (11000 BP - present) for sites in the case study region and 4 
additional sites from dissimilar landscapes (Lago Lungo, Ospitale, Lago Padule and Lago Pratignano) excluded from the regional synthesis.

Fig. 7 a) Anthropogenic Pollen Index (API) and b) OJC (Olea, Castanea and Juglans) index plotted for individual pollen sites (11000 BP - present) for sites in the case study region and 4 additional sites from dissimilar landscapes (Lago Lungo, Ospitale, Lago Padule and Lago Pratignano) excluded from the regional synthesis. 


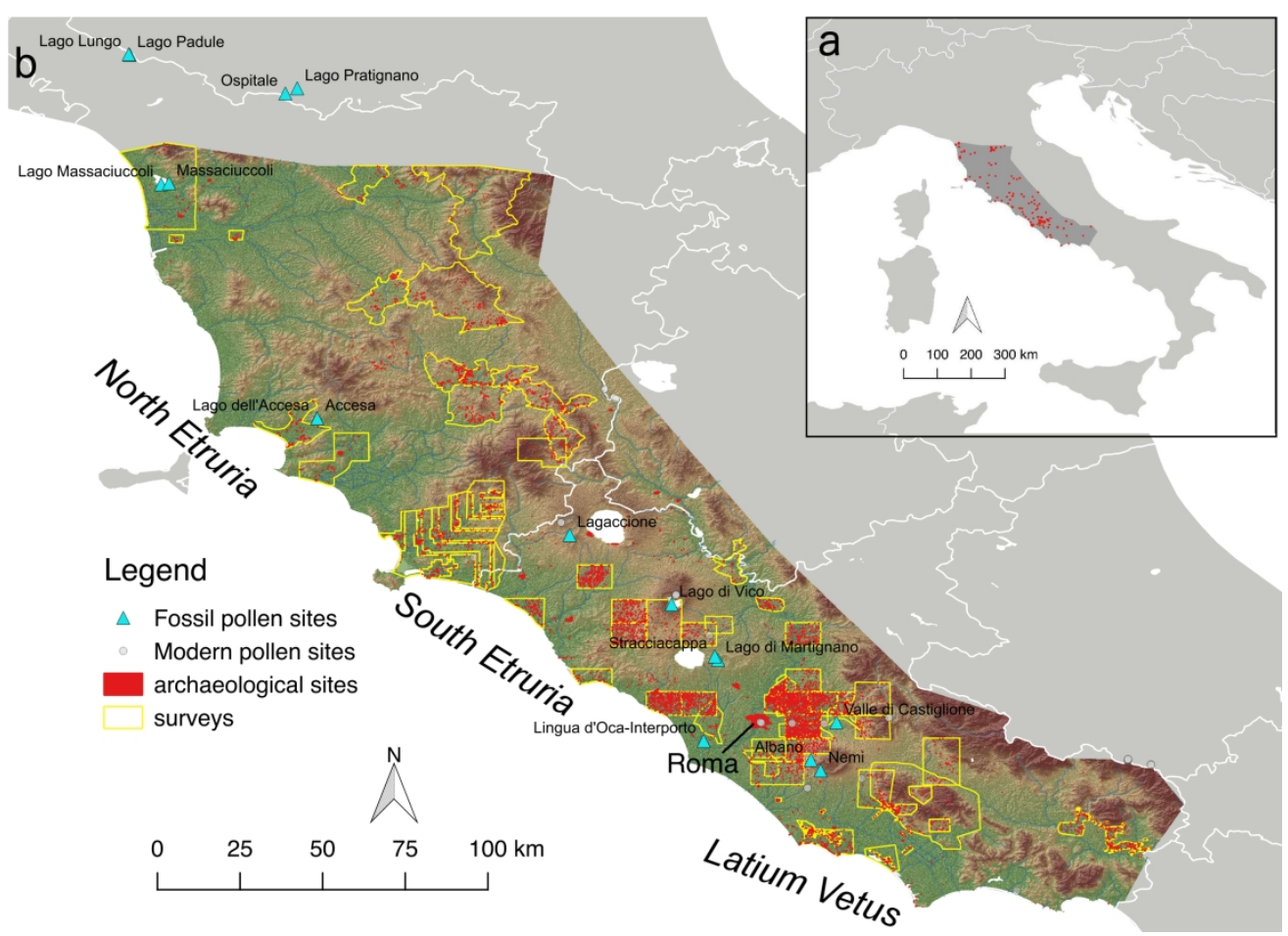

Fig. 1. Map showing the a) distribution of archaeological radiocarbon samples and b) archaeological sites and pollen archive sites (the yellow polygons indicate the boundary of the archaeological surveys).

$$
231 \times 166 \mathrm{~mm}(299 \times 299 \text { DPI })
$$




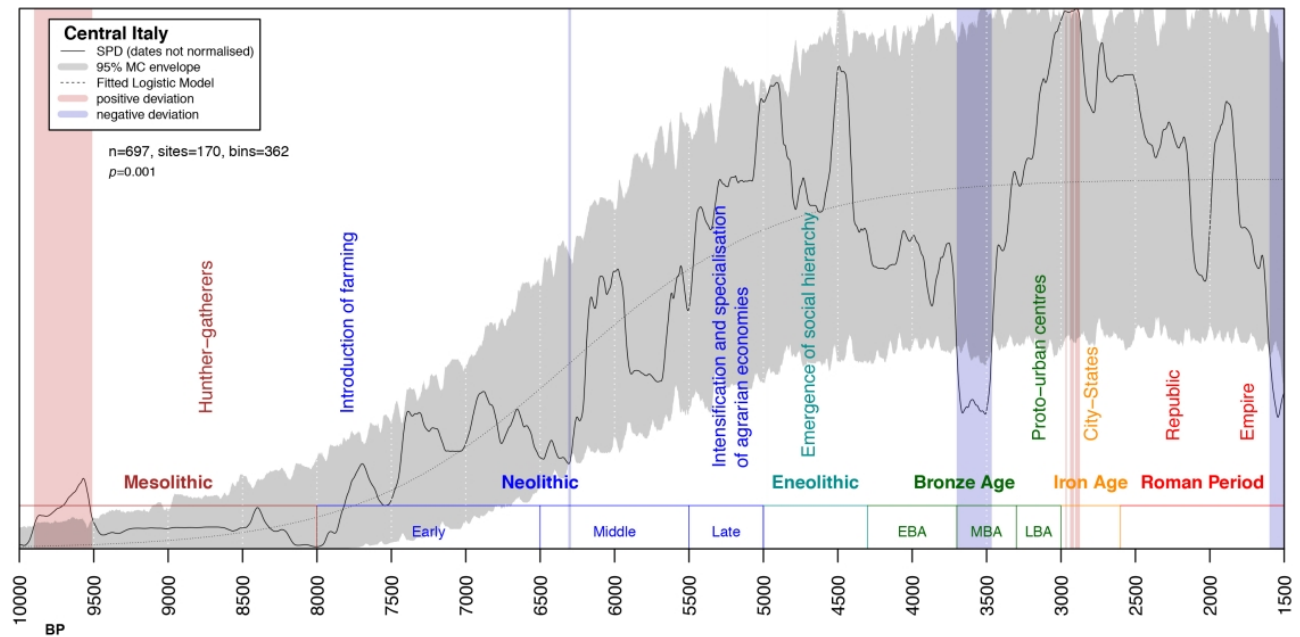

Fig. 2. Summed Probability Distribution (SPD) of unnormalised calibrated radiocarbon dates (solid line) vs. a fitted logistic model (95\% Monte-Carlo confidence grey envelope) of population growth.

$251 \times 124 \mathrm{~mm}(300 \times 300$ DPI $)$ 

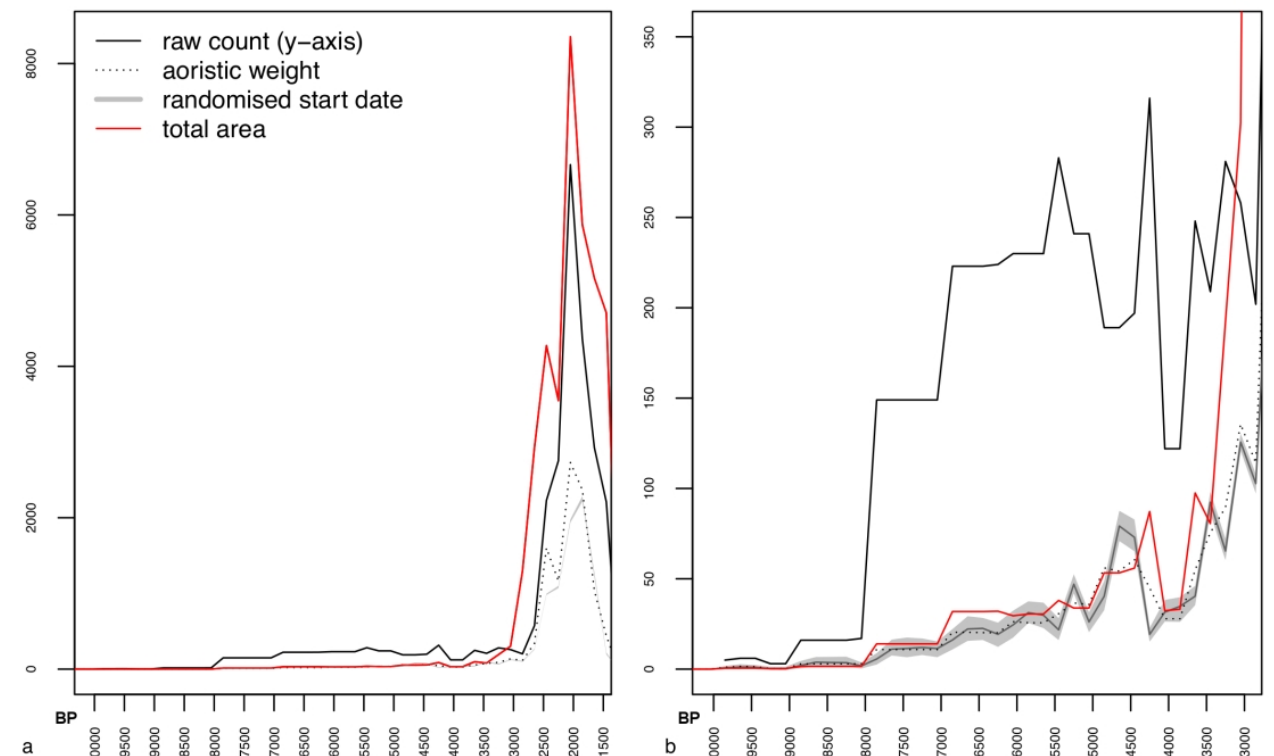

Fig. 3. a) Comparison of raw site count (solid line), summed settlement areas (red line), aoristic sum (dashed line), and randomised site start dates (grey envelope) from 10 to 1.5. ka BP; b) Inset of population change between 10 and $2.8 \mathrm{ka} \mathrm{BP}$.

$203 \times 127 \mathrm{~mm}(300 \times 300$ DPI $)$ 


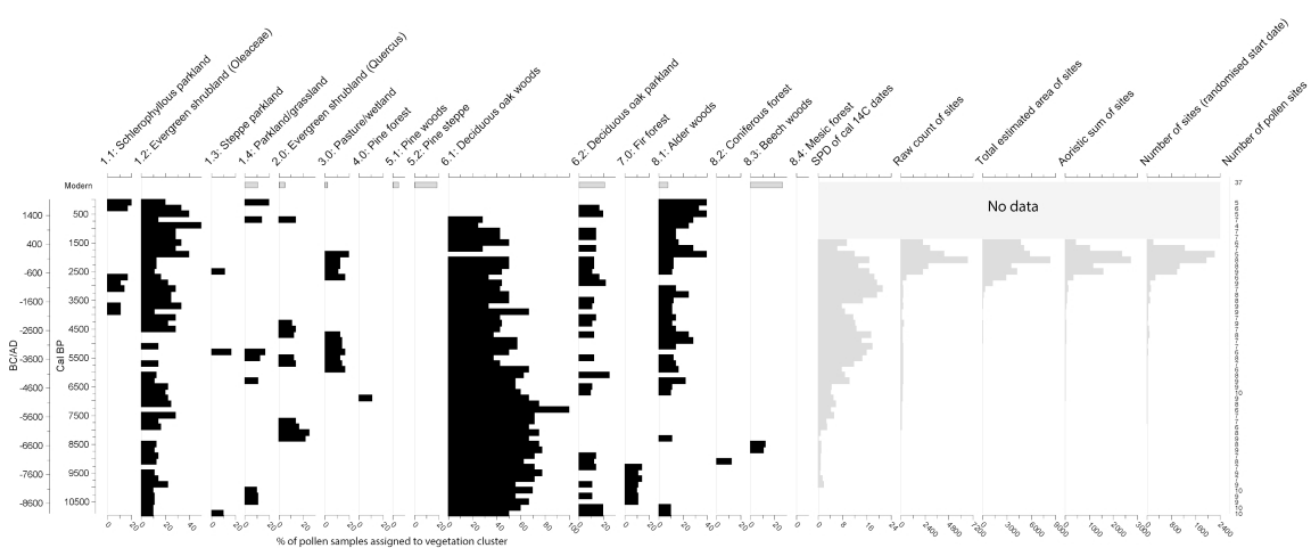

Fig. 4 Pollen-inferred vegetation cluster groups (11,000 BP - modern) for Tyrrhenian central Italy compared with proxy archaeological data. 


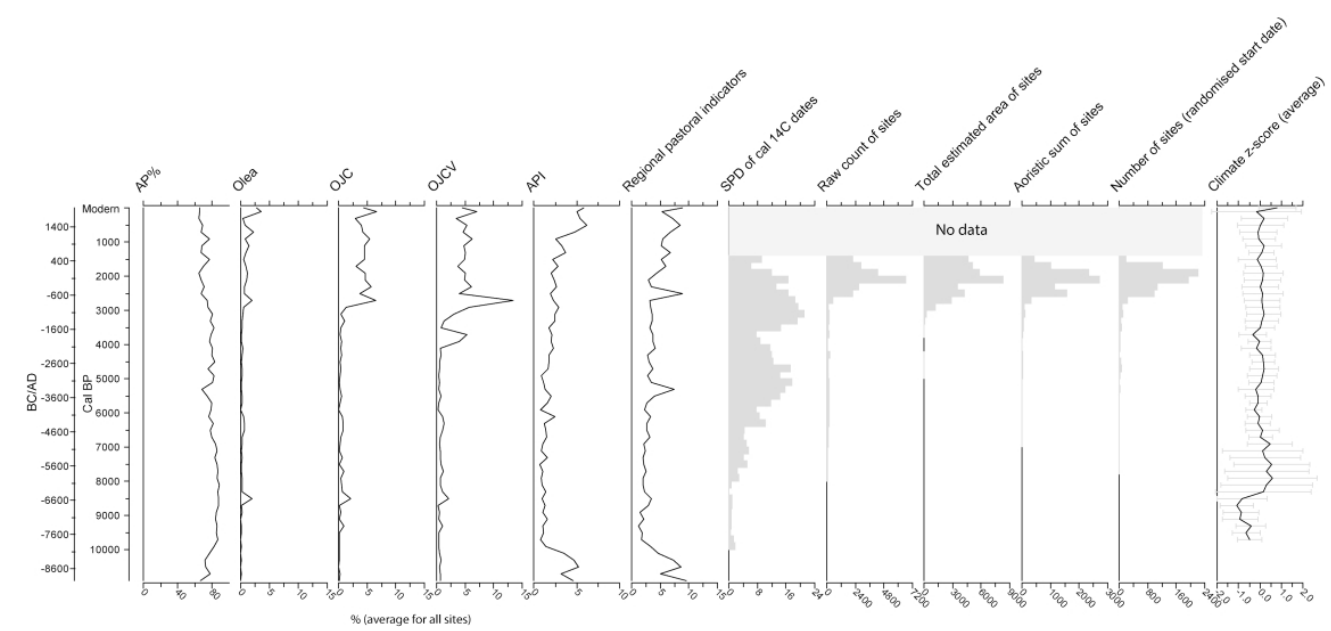

Fig. 5 Pollen indicator groups: arboreal pollen (\%AP), sum of Olea, Juglans, Castanea and Vitis $(\mathrm{O} / \mathrm{OJC} / \mathrm{OJCV})$, anthropogenic pollen index (API), and pastoral indicators averaged for all sites in the study area (11,000 BP to modern) compared with proxy archaeological data. Regional average z-scores are presented for 14 palaeoclimate records from across Italy (for further information about the palaeoclimate datasets see Finné et al., this volume). 


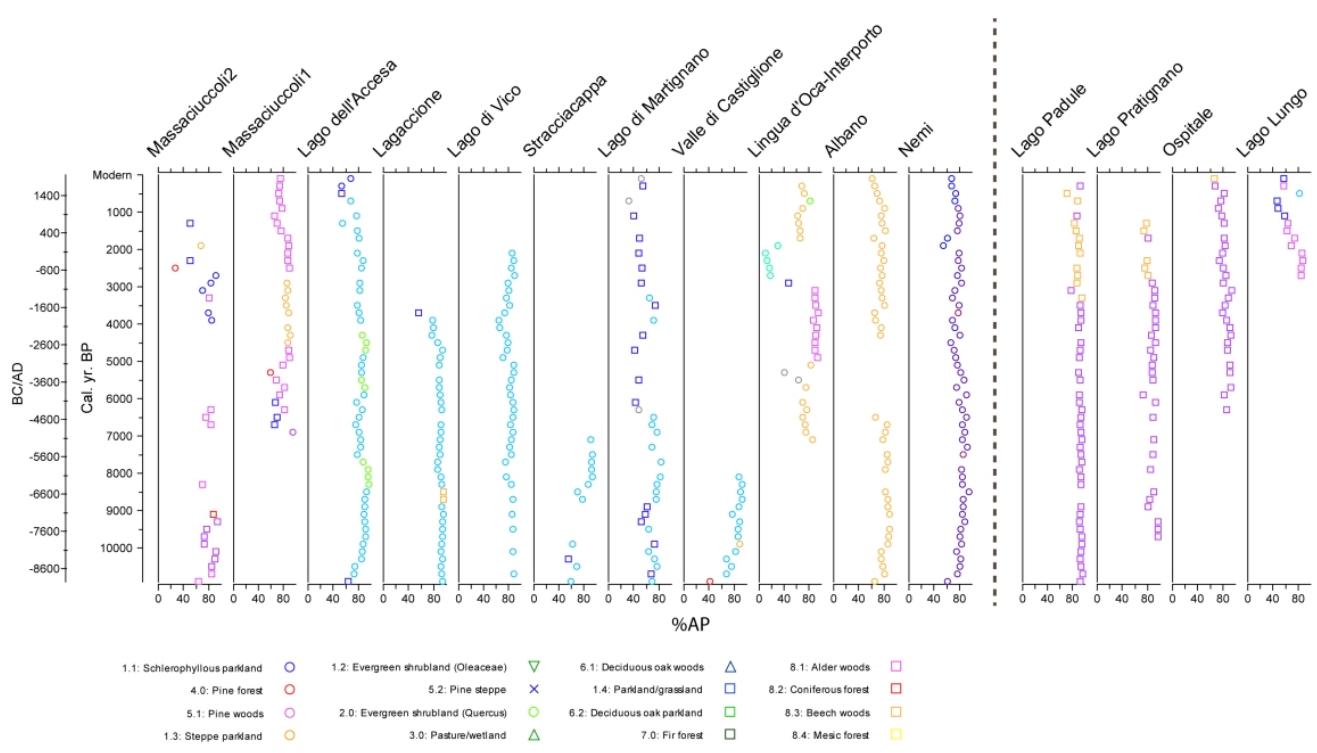

Fig. 6 Arboreal Pollen \% (AP\%) plotted in the $x$-axis for each pollen site plotted with cluster analysis derived vegetation cluster (symbols) (11000 BP - present) for sites in the case study region and 4 additional sites from dissimilar landscapes (Lago Lungo, Ospitale, Lago Padule and Lago Pratignano) excluded from the regional synthesis. 


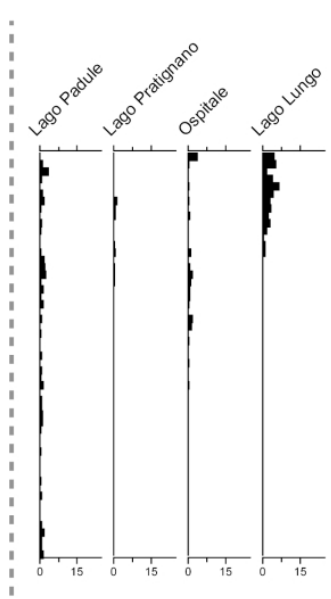

b) OJC (Olea, Juglans and Castanea) index

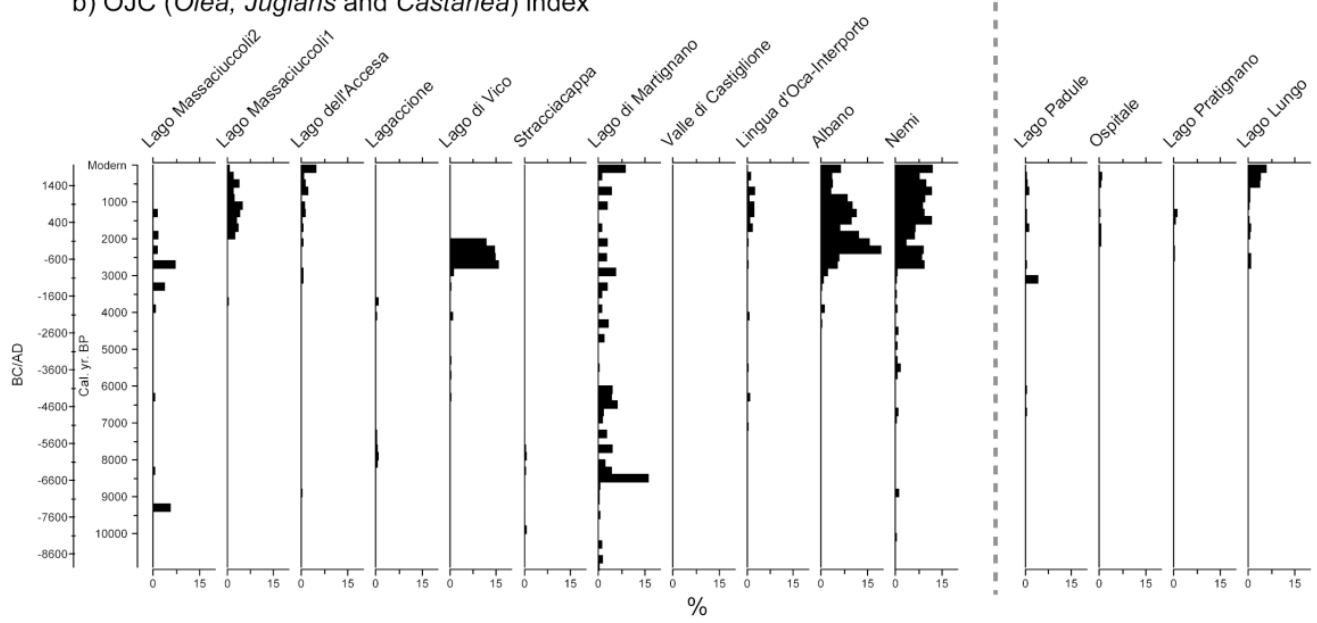

excluded from the regional synthesis.

Fig. 7 a) Anthropogenic Pollen Index (API) and b) OJC (Olea, Castanea and Juglans) index plotted for individual pollen sites (11000 BP - present) for sites in the case study region and 4 additional sites from dissimilar landscapes (Lago Lungo, Ospitale, Lago Padule and Lago Pratignano) excluded from the regional synthesis. 


\begin{tabular}{|c|c|c|}
\hline Period & \multicolumn{2}{|l|}{ Absolute dates } \\
\hline Mesolithic & \multicolumn{2}{|l|}{$10,000 / 9,500-6000 / 5800 \mathrm{BC} \mid 11950 / 11450-7950 / 7750 \mathrm{BP}$} \\
\hline Early Neolithic & \multicolumn{2}{|l|}{$6000 / 5800-4500 \mathrm{BC} \mid 7950 / 7750-6450 \mathrm{BP}$} \\
\hline Middle Neolithic & \multicolumn{2}{|l|}{$4500-3500 \mathrm{BC} \mid 6450-5450 \mathrm{BP}$} \\
\hline Late Neolithic & \multicolumn{2}{|l|}{$3500-3000 \mathrm{BC} \mid 5450-4950 \mathrm{BP}$} \\
\hline Chalcolithic & \multicolumn{2}{|l|}{$3000-2300 \mid 4950-4250 \mathrm{BP}$} \\
\hline Early Bronze Age & \multicolumn{2}{|l|}{$2300-1700 \mathrm{BC} \mid 4250-3650 \mathrm{BP}$} \\
\hline Middle Bronze Age & \multicolumn{2}{|l|}{$1700-1325 / 1300 \mathrm{BC} \mid 3650-3275 / 3250 \mathrm{BP}$} \\
\hline Recent Bronze Age & $1325 / 1300-1175 / 1150 \mathrm{BC} \mid 3275 / 3250-3125 / 3100 \mathrm{BP}$ & \multirow{2}{*}{$\begin{array}{c}\text { Late Bronze } \\
\text { Age }\end{array}$} \\
\hline Final Bronze Age & $1175 / 1150-1020 / 950 \mathrm{BC} \mid 3125 / 3100-2970 / 2900 \mathrm{BP}$ & \\
\hline Early Iron Age & \multicolumn{2}{|l|}{$1020 / 950-750 / 725$ BC | 2970/2900 - 2700/2675 BP } \\
\hline Late Iron Age & \multicolumn{2}{|l|}{$750 / 725-580 \mathrm{BC} \mid 2700 / 2675-2530 \mathrm{BP}$} \\
\hline Archaic Period & \multicolumn{2}{|l|}{$\begin{array}{l}580-480 \mathrm{BC} \\
22530-2430 \mathrm{BP}\end{array}$} \\
\hline Post-Archaic Period & \multicolumn{2}{|l|}{$480-350 \mathrm{BC} \mid 2430-2300 \mathrm{BP}$} \\
\hline Republican Period & \multicolumn{2}{|l|}{$350-30 \mathrm{BC} \mid 2300-1980 \mathrm{BP}$} \\
\hline Early Imperial Period & \multicolumn{2}{|l|}{$30 \mathrm{BC}-100 \mathrm{AD} \mid 1980-1850 \mathrm{BP}$} \\
\hline Mid-Imperial Period & \multicolumn{2}{|l|}{$100-300 \mathrm{AD} \mid 1850-1650 \mathrm{BP}$} \\
\hline Late Imperial Period & \multicolumn{2}{|l|}{$300-500 \mathrm{AD} \mid 1650 \mathrm{BP}-1450 \mathrm{BP}$} \\
\hline
\end{tabular}

Table 1. A chronological scheme for central Italy (after Guidi and Piperno 1993, Plate VI and X; Malone 2003, Table I; Attema et al. 2010, Table 2.1; Rajala 2013, Table 1; Fulminante 2014, Table 7; Alessandri 2016, Fig.2). 


\begin{tabular}{|c|c|c|c|c|c|c|c|}
\hline Code & Site name & Latitude & Longitude & Elevation & Contributor & Site type & Citation \\
\hline ACCESA & Accesa & 42.98667 & 10.89167 & 160 & Colombaroli & lake & $\begin{array}{l}\text { Colombaroli D et al. (2008) Fire vegetation interactions during the } \\
\text { Mesolithic Neolithic transition at Lago dell'Accesa, Tuscany, Italy. The } \\
\text { Holocene: } 18,679-692 \text {. }\end{array}$ \\
\hline MASSAC2 & Massaciuccoli & 43.81 & 10.22 & 0 & Colombaroli & lake & $\begin{array}{l}\text { Colombaroli D (2007) Long-term interactions between Mediterranean } \\
\text { climate, vegetation and fire regime at Lago di Massaciuccoli (Tuscany, Italy). } \\
\text { Journal of Ecology: } 95,755-770\end{array}$ \\
\hline CASTIG & $\begin{array}{l}\text { Valle di } \\
\text { Castiglione }\end{array}$ & 41.89167 & 12.75972 & 44 & Di Rita & $\begin{array}{l}\text { ancient } \\
\text { lake }\end{array}$ & $\begin{array}{l}\text { Di Rita F et al. (2013) A Lateglacial and early Holocene pollen record from } \\
\text { Valle di Castiglione (Rome): Vegetation dynamics and climate implications. } \\
\text { Quaternary International: } 288,73-80 .\end{array}$ \\
\hline DOCA & $\begin{array}{l}\text { Lingua d'Oca- } \\
\text { Interporto }\end{array}$ & 41.825 & 12.282 & 0 & Di Rita & coastal & $\begin{array}{l}\text { Di Rita F et al. (2010) Holocene environmental instability in the wetland } \\
\text { north of the Tiber delta (Rome, Italy): sea-lake-man interactions. Journal of } \\
\text { Paleolimnology: 44, 51-67. }\end{array}$ \\
\hline AC4HOLO & $\begin{array}{l}\text { Lago } \\
\text { dell'Accesa }\end{array}$ & 42.98667 & 10.89167 & 160 & EPD & lake & $\begin{array}{l}\text { Drescher-Schneider RE et al. (2007) Vegetation history, climate and human } \\
\text { impact over the last } 15,000 \text { years at Lago dell'Accesa (Tuscany, Central Italy). } \\
\text { Vegetation History and Archaeobotany: } 16,279-299 .\end{array}$ \\
\hline AC4LATE & $\begin{array}{l}\text { Lago } \\
\text { dell'Accesa }\end{array}$ & 42.98667 & 10.89167 & 160 & EPD & lake & $\begin{array}{l}\text { Drescher-Schneider RE (2007) Vegetation history, climate and human impact } \\
\text { over the last 15,000 years at Lago dell'Accesa (Tuscany, Central Italy). } \\
\text { Vegetation History and Archaeobotany, 16:279-299. }\end{array}$ \\
\hline MARTIGAN & $\begin{array}{l}\text { Lago di } \\
\text { Martignano }\end{array}$ & 42.11667 & 12.33333 & 204 & EPD & maar lake & $\begin{array}{l}\text { Kelly MG et al. (1991) An } 11000 \text { year record of vegetation and environment } \\
\text { from Lago di Mortignara, Latium, Italy. Journal of Quaternary Science: 6, } \\
\text { 209-224. }\end{array}$ \\
\hline STRACC & Stracciacappa & 42.13 & 12.32194 & 220 & Giardini & $\begin{array}{l}\text { drained } \\
\text { crater lake }\end{array}$ & $\begin{array}{l}\text { Giardini M (2007) Late Quaternary vegetation history at Stracciacappa } \\
\text { (Rome, central Italy). Vegetation History and Archaeobotany: 16, 301-316. }\end{array}$ \\
\hline LAGACC & Lagaccione & 42.56667 & 11.8 & 355 & Magri & lake & $\begin{array}{l}\text { Magri D (1999) Late Quaternary vegetation history at Lagaccione near Lago } \\
\text { di Bolsena (central Italy). Review of Palaeobotany and Palynology: 106, 171- } \\
208 .\end{array}$ \\
\hline MASSAC & Lago & 43.83 & 10.33 & 0 & Mariotti & lake & Menozzi BI et al. (2003) Lineamenti paleoambientali del bacino del Lago di \\
\hline
\end{tabular}




\begin{tabular}{|c|c|c|c|c|c|c|c|}
\hline & Massaciuccoli & & & & & & $\begin{array}{l}\text { Massaciuccoli (Toscana Nord-occidentale, Italia). Atti Soc Tosc Sci Nat, Serie } \\
\text { B: 109, 177-187. }\end{array}$ \\
\hline ALBANO & Albano & 41.756 & 12.667 & 0 & Mercuri & lake & $\begin{array}{l}\text { Mercuri AM et al. (2002) The long history of Cannabis and its cultivation by } \\
\text { the Romans in central Italy, shown by pollen records from Lago Albano and } \\
\text { Lago di Nemi. Vegetation History and Archaeobotany: 11, 263-276. }\end{array}$ \\
\hline NEMI & Nemi & 41.718 & 12.702 & 0 & Mercuri & lake & $\begin{array}{l}\text { Mercuri AM et al. (2002) The long history of Cannabis and its cultivation by } \\
\text { the Romans in central Italy, shown by pollen records from Lago Albano and } \\
\text { Lago di Nemi. Vegetation History and Archaeobotany: } 11,263-276 \text {. }\end{array}$ \\
\hline VICO & Lago di Vico & 42.31667 & 12.16667 & 510 & Sadori & lake & $\begin{array}{l}\text { Magri D \& Sadori L (1999) Late Pleistocene and Holocene pollen stratigraphy } \\
\text { at Lago di Vico, central Italy. Vegetation History and Archaeobotany: 8, 247- } \\
260 \text {. }\end{array}$ \\
\hline LUN & Lago Lungo & 42.47 & 12.83 & 369 & Mensing & lake & $\begin{array}{l}\text { Mensing SA et al. (2015) } 2700 \text { years of Mediterranean environmental } \\
\text { change in central Italy: a synthesis of sedimentary and cultural records to } \\
\text { interpret past impacts of climate on society. Quaternary Science Reviews: } \\
\text { 116, 72-94. }\end{array}$ \\
\hline PADULE & Lago Padule & 44.29861 & 10.21472 & 1187 & EPD & lake & $\begin{array}{l}\text { Watson CS (1996) The vegetational history of the northern Apennines, Italy: } \\
\text { information from three new sequences and a review of Regional } \\
\text { vegetational change. Journal of Biogeography: } 23,805-841 \text {. }\end{array}$ \\
\hline PRGNP & $\begin{array}{l}\text { Lago } \\
\text { Pratignano }\end{array}$ & 44.17611 & 10.81972 & 1307 & EPD & $\begin{array}{l}\text { Bog with } \\
\text { central } \\
\text { open water }\end{array}$ & $\begin{array}{l}\text { Watson CS (1996). The vegetational history of the northern Apennines, Italy: } \\
\text { information from three new sequences and a review of Regional } \\
\text { vegetational change. Journal of Biogeography: } 23,805-841 \text {. }\end{array}$ \\
\hline OSPITALE & Ospitale & 44.15556 & 10.78 & 1225 & EPD & $\begin{array}{l}\text { circular } \\
\text { bog }\end{array}$ & $\begin{array}{l}\text { Watson CS (1996). The vegetational history of the northern Apennines, Italy: } \\
\text { information from three new sequences and a review of Regional } \\
\text { vegetational change. Journal of Biogeography: } 23,805-841 \text {. }\end{array}$ \\
\hline
\end{tabular}




$-0.47$

$-0.72$

\begin{tabular}{l|l|l|l|l|l|}
-0.72 & 0.39 & 0.37 & 0.45 & 0.68
\end{tabular}

Table 3. Spearman's Rank Correlation Coefficient (R-values) value matrix for the period 10000-1400 cal BP. In bold values significant correlations ( $p$-value $<0.05$ ). 


\section{Supplemental material 1}

\section{Radiocarbon dates}

Radiocarbon dates from archaeological sites were compiled from existing online databases and electronic and print. A total of 697 uncalibrated radiocarbon dates from 170 sites have been collected. Below the sources from which the radiocarbon dates have been collected.

\section{Databases/Datasets}

BANADORA. Banque Nationale de Données Radiocarbonne pour l'Europe et le Proche Orient, Centre de Datation par le Radiocarbonne, CNRS Lyon: http://www.arar.mom.fr/banadora/

CalPal - The Cologne Radiocarbon Calibration \& Palaeoclimate Research Package. Developed by Weninger, B., Jöris, O., and Danzeglocke, U: http://monreposrgzm.de/forschung/ausstattung.html\#calpal

EUROEVOL. Manning, K; Timpson, A; Colledge, S; Crema, E; Shennan, S; (2015) The Cultural Evolution of Neolithic Europe. EUROEVOL Dataset: http://discovery.ucl.ac.uk/1469811/

IRPA/KIK. Royal Institute for Cultural Heritage web based Radiocarbon database. Van Strydonck, M. and De Roock, E., 2011. Royal Institute for Cultural Heritage web-based radiocarbon database. Radiocarbon, 53(2), pp.367-370.

http://c14.kikirpa.be/

ORAU. Oxford Radiocarbon Accelerator Unit online database:

https://c14.arch.ox.ac.uk/databases.html

RADON. Martin Hinz, Martin Furholt, Johannes Müller, Dirk Raetzel-Fabian, Christoph Rinne, Karl-Göran Sjögren, Hans-Peter Wotzka, RADON - Radiocarbon dates online 2012. Central European database of ${ }^{14} \mathrm{C}$ dates for the Neolithic and Early Bronze Age. www.jungsteinsite.de, 2012, 1-4: http://radon.ufg.uni-kiel.de/

\section{References}

Alessio, M., Bella, F. and Cortesi, C., 1964. University of Rome carbon-14 dates II. Radiocarbon, 6, pp.77-90.

Alessio, M., Bella, F., Bachechi, F. and Cortesi, C., 1965. University of Rome carbon14 dates III. Radiocarbon, 7, pp.213-222.

Alessio, M., Bella, F., Bachechi, F. and Cortesi, C., 1967. University of Rome carbon14 dates V. Radiocarbon, 9, pp.346-367. 
Alessio, M., Bella, F., Improta, S., Belluomini, G., Cortesi, C. and Turi, B., 1970. University of Rome carbon-14 dates VIII. Radiocarbon, 12(2), pp. 599-616.

Alessio, M., Bella, F., Improta, S., Belluomini, G., Calderoni, G., Cortesi, C. and Turi, B., 1974. University of Rome carbon-14 dates XII. Radiocarbon, 16(3), pp.358-367.

Alessio, M., Bella, F., Improta, S., Belluomini, G., Calderoni, G., Cortesi, C., Manelli, G.L. and Vigilante, A., 1975. University of Rome carbon-14 dates XIII. Radiocarbon, 17(3), pp.313-327.

Alessio, M., Bella, F., Improta, S., Belluomini, G., Calderoni, G., Cortesi, C. and Turi, B., 1976. University of Rome carbon-14 dates XIV. Radiocarbon, 18(3), pp.321-349.

Alessio, M., Allegri, L., Bella, F., Improta, S., Belluomini, G., Calderoni, C., Cortesi, C., Manfra, L., Petrone, V. and Fruscalzo, A., 1978. University of Rome carbon-14 dates XV. Radiocarbon, 20(1), pp.68-78.

Ambers, J. and Bowman, S., 1998. Radiocarbon measurements from the British Museum: datelist XXIV. Archaeometry, 40(2), pp.413-435.

Ambers, J. and Bowman, S., 1999. Radiocarbon measurements from the British Museum: datelist XXV. Archaeometry, 41(1), pp.185-195.

Ambers, J., Matthews, K.J. and Bowman, S., 1989. British Museum natural radiocarbon measurements XXI. Radiocarbon, 31(1), pp.15-32.

Anzidei, A.P., Carboni, G., Castagna, M.A., Celant, A., Cianca, M., Egidi, R., Favorito, S., Funiciello, R., Giordano, G., Malvone, M. and Tagliacozzo, A., 2007. L'abitato eneolitico di Osteria del Curato-via Cinquefrondi: nuovi dati sulle facies archeologiche di Laterza e Ortucchio nel territorio di Roma. Atti della XL Riunione Scientifica dell'Instituto Italiano di Preistoria e Protostoria. Strategie di insediamento fra Lazio e Campania in età preistorica e protostorica, pp.477-508.

Anzidei, A.P., Carboni, G., Carboni, L., Castagna, M.A. and Catalano, P., 2011. Il gruppo Roma-Colli Albani della facies di Rinaldone: organizzazione spaziale, rituali e cultura materiale nelle necropoli di Lucrezia Romana e Romanina, Roma. Atti della XLIII Riunione scientifica, pp.297-307.

Azzi, C.M., Bigliocca, L. and Piovan, E., 1973. Florence radiocarbon dates I. Radiocarbon, 15(3), pp.479-487.

Azzi, C.M., Bigliocca, L. and Piovan, E., 1974. Florence radiocarbon dates II. Radiocarbon, 16(1), pp.10-14.

Babbi, A., Peltz, U. and Benelli, E., 2016. La tomba del guerriero di Tarquinia: identita elitaria, concentrazione del potere e networks dinamici nell'avanzato VIII sec. $a C$. Verlag des Römisch-Germanischen Zentralmuseums; [Schnell+ Steiner.

Brock, A.L. and Terrenato, N., 2016. Rome in the Bronze Age: late secondmillennium BC radiocarbon dates from the Forum Boarium. Antiquity, 90(351), pp.654-664. 
Bronk Ramsey, C., Higham, T.F.G., Brock, F., Baker, D., Ditchfield, P. and Staff, R.A., 2015. Radiocarbon dates from the Oxford AMS System: archaeometry Datelist 35. Archaeometry, 57(1), pp.177-216.

Calabrisotto, C.S., Fedi, M.E., Taccetti, F., Benvenuti, M., Chiarantini, L. and Quaglia, L., 2009. Radiocarbon Reveals the Age of Two Precious Tombs in the Etruscan Site of Populonia-Baratti (Tuscany). Radiocarbon, 51(3), pp.915-922.

Capuzzo, G., Boaretto, E. and Barceló, J.A., 2014. EUBAR: A Database of 14 C Measurements for the European Bronze Age. A Bayesian Analysis of 14 C-Dated Archaeological Contexts from Northern Italy and Southern France. Radiocarbon, 56(2), pp.851-869.

Catachhio, Nuccia Negroni, Aspesi, Matteo, 2013. La cronologia di Rinaldone: lo stato della questione e le nuove datazioni. Preshitroia E Protostoria: Chronologia Assoluta e Relativa Della'eta Del Rame in Italia. Universita de Verona. Qui Edit, Verona.

Conti, Anna Maria; Persiani, Carlo; Pettini, Patrizia. 1997. I Riti Della Morte Nella Necropoli Eneolitica Della Selvicciola (Ischia de Castro-Viterbo). Origini: Preistoria e Protostoria Delle Civilta Antiche. Bonsignori Editore.

Dauchot, D.M. and Van, S.M., 1981. Institut Royal du Patrimoine Artistique radiocarbon dates XII. Radiocarbon, 29(2), pp.197-208.

Dauchot-Dehon, M., Van Strydonck, M. and Heylen, J., 1981. Institut Royal du Patrimoine Artistique radiocarbon dates VIII. Radiocarbon, 23(3), pp.345-351.

De Marinis, R., 2001. Aspetti della Metallurgia dell'Antica Eta' del Bronzo in Toscana. Atti della XXXIV Riunione Scientifica . Preistoria e Protostoria della Toscana. Firenze: Istituto Italiano di Preistoria e Protostoria, 253-281.

Fedi, M.E., Arnoldus-Huyzendveld, A., Cartocci, A., Manetti, M. and Taccetti, F., 2007. Radiocarbon dating in late-Roman and medieval contexts: an archaeological excavation in the Center of Florence, Italy. Radiocarbon, 49(2), pp.611-616.

Fentress, E., Judson, S., Blagg, T., de Vos, M. and Arthur, P., 1983. Excavations at Fosso della Crescenza, 1962. Papers of the British School at Rome, 51, pp.58-101.

Fentress, E. and Bodel, J.P., 2003. Cosa 5 (Vol. 2). University of Michigan Press.

Fenwick, C., 2016. The Brick Building' in E. Fentress, C. Goodson, M. Maiuro (eds.) An Imperial Estate and its Legacies: Villamagna, near Anagni. British School of Rome Monograph Series: 184-7.

Ferrara, G., Reinharz, M. and Tongiorgi, E., 1959. Carbon-14 dating in Pisa. Radiocarbon, 1, pp.103-110.

Ferrara, G., Fornaca-Rinaldi, G. and Tongiorgi, E., 1961. Carbon-14 dating in PisaII. Radiocarbon, 3, pp.99-104.

Goiran, J.P., Salomon, F., Mazzini, I., Bravard, J.P., Pleuger, E., Vittori, C., Boetto, G., Christiansen, J., Arnaud, P., Pellegrino, A. and Pepe, C., 2014. Geoarchaeology 
confirms location of the ancient harbour basin of Ostia (Italy). Journal of Archaeological Science, 41, pp.389-398.

Goiran, J.P., Salomon, F., Bukowiecki, E. and Boetto, G., 2012. Portus. Relations entre des carottages dans les bassins et sur les structures portuaires (Secteur des Grandi Magazzini, de la Darsena et du chenal d'accès). Chronique des activités archéologiques de l'École française de Rome.

Jean-Philippe Goiran, Ferréol Salomon, Hervé Tronchère, Hatem Djerbi, Pierre Carbonel, Carole Ognard et Christine Oberlin, « Géoarchéologie des ports de Claude et de Trajan, Portus, delta du Tibre », Mélanges de l'École française de Rome Antiquité [En ligne], 123-1 | 2011, mis en ligne le 20 février 2013, consulté le 14 juin 2018. URL : http://journals.openedition.org/mefra/491 ; DOI : 10.4000/mefra.491

Cremonesi, R.G., 2001. Le Néolithique ancien de Toscane et de l'Archipel toscan. Bulletin de la Société préhistorique française, pp.423-430.

Hadler, H., Vött, A., Fischer, P., Ludwig, S., Heinzelmann, M. and Rohn, C., 2015. Temple-complex post-dates tsunami deposits found in the ancient harbour basin of Ostia (Rome, Italy). Journal of Archaeological Science, 61, pp.78-89.

Huiyzendveld, A. A., Turi, A., and Morelli, C., 2015. Il paleoambiente di Monte Giulio e della parte nord-orientale del bacino portuale di Claudio. Fasti Online. http://www.fastionline.org/docs/FOLDER-it-2015-324.pdf

Lawn, B., 1974. University of Pennsylvania radiocarbon dates XVII. Radiocarbon, 16(2), pp.219-237.

Lawn, B., 1975. University of Pennsylvania radiocarbon dates XVIII. Radiocarbon, 17(2), pp.196-215.

Maffi, M. and Tirabassi, I., 2013. Il sito Neolitico di S. Ilario d'Enza (Reggio Emilia): scavi Monaco-Bernardi. Rivista di scienze preistoriche, 63(63), pp.39-76.

Manfredini, A., Fugazzola Delpino, M.A., Sarti, L., Silvestrini, M. and Martini, F., 2009. Adriatico e Tirreno a confronto: analisi dell'occupazione territoriale tra il Neolitico finale e l'età del Rame in alcune aree campione dell'Italia centrale. Rivista di scienze preistoriche, 59(59), pp.115-179.

Manfredini, A., 2012. La cronologia dell'Eneolitico del Tirreno centrale alla luce delle recenti datazioni radiometriche. In: N. Negroni Catacchio (ed.), Preistoria e Protostoria in Etruria. L'Etruria dal Paleolitico al Primo Ferro. Atti del Decimo Incontro di Studi. Milano: Centro di Studi di Preistoria e Protostoria e Archeologia, 275-281.

Negroni Catacchio, N., Pacciani, E., Albertini, E., Aspesi, M. and Moggi-Cecchi, J., 2014. Nuovi dati su alcune necropoli rinaldoniane: revisione di vecchi scavi, nuove datazioni e recenti analisi dei resti scheletrici. Rivista di scienze preistoriche, 64(64), pp.83-113.

Nijboer, A.J., van der Plicht, J.O., Sestieri, A.B. and de Santis, A.N.N.A., 2015. A high chronology for the early Iron Age in central Italy. Palaeohistoria, pp.165-176. 
Olsson, I.U. and Kilicci, S., 1964. Uppsala natural radiocarbon measurements IV. Radiocarbon, 6, pp.291-307.

Ferréol Salomon, Jean-Philippe Goiran, Elisa Pleuger, Ilaria Mazzini, Antonia Arnoldus-Huyzendveld, Alessandra Ghelli, Giulia Boetto et Paola Germoni, « Ostie et l'embouchure du Tibre », Chronique des activités archéologiques de l'École française de Rome [En ligne], Italie centrale, mis en ligne le 28 janvier 2014, consulté le 14 juin 2018. URL : http://journals.openedition.org/cefr/1062 ; DOI : $10.4000 /$ cefr. 1062

Pearce, M.J., 2013. Rethinking the north Italian early Neolithic. Accordia Research Institute, University of London.

Pinhasi, R., Fort, J. and Ammerman, A.J., 2005. Tracing the origin and spread of agriculture in Europe. PLoS biology, 3(12), p.e410.

Ringbom, Å., Hale, J., Heinemeier, J., Lindroos, A., Brock, F. and Dunkeld, M., 2006. The use of mortar dating in archaeological studies of Classical and Medieval structures. In Proceedings of the Second International Congress on Construction History (Vol. 3, pp. 2613-33).

Rolfo, M.F., Achino, K.F., Fusco, I., Salari, L. and Silvestri, L., 2016. Reassessing human occupation patterns in the inner central Apennines in prehistory: The casestudy of Grotta Mora Cavorso. Journal of Archaeological Science: Reports, 7, pp.358-367.

Rutgers, L.V., van der Borg, K., de Jong, A.F., van der Linde, C. and Prins, J., 2007. Further radiocarbon dates from the catacombs of St. Callixtus in Rome. Radiocarbon, 49(3), pp.1221-1229.

Sadori, L., Giardini, M., Giraudi, C. and Mazzini, I., 2010. The plant landscape of the imperial harbour of Rome. Journal of Archaeological Science, 37(12), pp.3294-3305.

Salomon, F., Delile, H., Goiran, J.P., Bravard, J.P. and Keay, S., 2012. The Canale di Comunicazione Traverso in Portus: the Roman sea harbour under river influence (Tiber delta, Italy). Géomorphologie: relief, processus, environnement, 18(1), pp.7590 .

Schiappelli, A., 2008. Sviluppo Storico della Tiberina nell'Eta' del Bronzo e nella prima eta' del Ferro. Firenze: All'Insegna del Giglio, 210.

Shennan, S. and Steele, J., 2000. Spatial and chronological patterns in the neolithisation of Europe.

http://archaeologydataservice.ac.uk/archives/view/c14 meso/downloads.cfm

Skeates, R., 1994. A radiocarbon date-list for prehistoric Italy (c. 46400 BP-2450 $\mathrm{BP} / 400$ cal. BC). Radiocarbon dating and italian prehistory, 3, pp.147-288.

Skeates, R., 1996. Towards an absolute chronology for the Copper Age in central Italy: a note based on the Conelle site and culture. Papers of the British School at Rome, 64, pp.273-282. 
Skeates, R., 2001. New radiocarbon dates for prehistoric Italy and Malta. Accordia Research Papers, 8, pp.165-186.

Skeates, R., 2003. New radiocarbon dates for prehistoric Italy: supplementary list 5. Accordia research papers., 9, pp.163-182.

Skeates, R. and Whitehouse, R., 1996. New radiocarbon dates for prehistoric Italy 1. The Accordia Research Papers, 5(1993-94), pp.137-150.

Skeates, R., and Whitehouse, R., 1996-7. New radio carbon dates for prehistoric Italy 2. The Accordia Research Papers 6: 179-91

Skeates, R., and Whitehouse, R., 1997-8. New radio carbon dates for prehistoric Italy 3. The Accordia Research Papers 7: 149-62.

Trautman, M.A. and Willis, E.H., 1966. Isotopes, Inc. radiocarbon measurements V. Radiocarbon, 8, pp.161-203.

Van Der Plicht, J., Bruins, H.J. and Nijboer, A.J., 2009. The Iron Age around the Mediterranean: a High Chronology perspective from the Groningen radiocarbon database. Radiocarbon, 51(1), pp.213-242.

van Rossenberg, E.A. and Rossenberg, E.A.V.E., 2012. Cultural landscapes, social networks and historical trajectories: A data-rich synthesis of Early Bronze Age networks (c. 2200-1700 BC) in Abruzzo and Lazio (Central Italy) (Doctoral dissertation, Faculty of Archaeology, Leiden University).

Visentini, P. 2006. Aspetti cronologici e culturali della fine del Neolitico nell'Italia nord-orientale. In: Pessina, A., and Visentini, P. (eds.), Preistoria dell' Italia settentrionale. Studi in ricordo di Bernardino Bagolini Atti del Convegno, Udine: Comune di Udine, Edizioni del Museo friulano di storia naturale, pp. 225-242.

\section{Archaeological Settlement Data}


Archaeological settlement data sites were compiled from existing published archaeological survey reports. A total of 7,074 archaeological sites and 10,758 occupation phases have been collected. Below the sources from which the archaeological sites have been collected.

\section{References}

Acconcia, V., 2012. Paesaggi etruschi in terra di Siena. Oxford: Archeopress (BAR International Series, 2422)

Alessandri, L., 2007. L'occupazione costiera protostorica nel Lazio centromeridionale. Oxford: Archaeopress (BAR International Series, 1592)

Alessandri, L., 2013. Latium Vetus in the Bronze Age and Early Iron Age. Oxford: Archaeopress (BAR International Series, 2565).

Andreussi, M., 1977. Vicus Matrini. Forma Italiae, Regio VII -4. Roma: De Luca.

Anzidei, A. P. et al., 2007.L'abitato eneolitico di Osteria del Curato-via Cinquefrondi: nuovi dati sulle facies archeologiche di Laterza e Ortucchio nel territorio di Roma. In: Atti XL Riunione scientifica IIPP. Firenze: Istituto Italiano di Preistoria e Protostoria, 477-508.

Attema, P., 1993. An archaeological survey in the Pontine Region?: a contribution to the early settlement of South Lazio. Unpublished PhD thesis. University of Groningen.

Attema, P. A. J., De Haas, T. C. A. and La Rosa, M., 2005. Sites of the Fogliano survey (Pontine Region, central Italy), site classification and a comment on the diagnostic artefacts from Prehistory to the Roman period, Palaeohistoria 45/46, 121196.

Attema, P. A. J. et al., 2007. The Astura and Nettuno surveys of the Pontine Region Project (2003-2005, 1st report). Palaeohistoria, 49/50, 415-516.

Attema, P. A. J., De Haas, T. C. A. and Tol, G. W., 2009-2010. The Astura and Nettuno surveys of the Pontine region project (2003 - 2005), 2nd and final report. Palaeohistoria, 51/52, 169-327.

Attema, P. A. J., Burgers, G. J. and van Leusen, P. M., 2010. Regional pathways to complexity?: settlement and land-use dynamics in early Italy from the Bronze Age to the Republican period. Amsterdam: Amsterdam University Press.

Attema, P. A. J., De Haas, T. C. A. and Tol, G. W. 2014. Villas and farmsteads in the Ager Setinus (Sezze, Italy). Palaeohistoria 55/56, 177-244.

Barbaro, B., 2010. Insediamenti, aree funerarie ed entita' territoriali in Etruria meridionale nel Bronzo Finale. Firenze: All'Insegna del Giglio. 
Bietti Sestrieri, A. M., 1984. Preistoria e Protostoria nel territorio di Roma. Roma: De Luca.

Borghi, R., 2002. Chiusi. Roma: 'L'Erma' di Bretschneider.

Botarelli, L., 2004. Radicofani. Carta Archeologica della Provincia di Siena, VII. Siena: Nuova Immagine Editrice.

Brandizzi Vittucci, P., 1968. Cora. Forma Italiae, 5. Roma: De Luca Editore.

Cambi, F., 1996. Carta Archeologica della Provincia di Siena II. Il Monte Amiata (Abbadia San Salvatore). Siena: Nuova Immagine Editrice.

Campana, S., 2001. Murlo. Carta Archeologica della Provincia di Siena, 5. Siena: Nuova Immagine Editrice.

Campana, S., 2013. Montalcino. Carta Archeologica della Provincia di Siena, XII. Siena: Nuova Immagine Editrice.

Carandini, A., Cambi, F., Celuzza, M., and Fentress, E., 2002. Paesaggi d'Etruria. Roma: Edizioni di Storia e Letteratura.

Carboni, G., 2002. Territorio aperto o di frontiera? Nuove prospettive di ricerca per lo studio della distribuzione spaziale delle facies del Gaudo e di Rinaldone nel Lazio centro-Meridionale. Origini 24, 235-299.

Cascino, R., di Giuseppe, H. and Patterson, H., 2012. Veii. The Historical Topography of the Ancient City. London: The British School at Rome.

Cenni, F. , 2010. Buonconvento. Carta Archeologica della Provincia di Siena, VIII. Siena: Nuova Immagine Editrice.

Chellini, R., 2012. Carta Archeologica della Provincia di Firenze. Galatina: Congedo.

Chiarucci, P., 1996. La documentazione archeologica pre-protostorica nell'area albana e le piu' recenti scoperte. In: Pasqualini, A. (editor), Alba Longa. Mito Storia Archeologia. Atti dell'incontro di studio. Roma - Albano Laziale 27-29 gennaio 1994. Roma: Istituto Italiano per la Storia Antica, 1-27.

Corsi, C., 2000. L'insediamento rurale di eta' romana e tardoantica nel territorio tra Tarquinia e Vulci. II parte. Journal of Ancient Topography 10, 205-276.

Cucini, C., 1985. Topografia del territorio delle valli del Pecora e dell'Almo. In: Francovich, R. (ed.), Scarlino I. Storia e Territorio. Firenze: All'Insegna del Giglio, 147.

Curri, C. B., 1978. Vetulonia I. Forma Italiae, Regio VII -5. Firenze: Leo Olschki. de Haas, T., 2011. Fields, farms and colonists: Intensive field survey and early Roman colonization in the Pontine region, central Italy. Groningen: University of Groningen.

De Rossi, G. B., 1967. Tellenae. Roma: Consiglio Nazionale delle Ricerche.

De Rossi, G. B., 1970. Apiolae. Forma Italiae, 9. Roma: Consiglio Nazionale delle Ricerche. 
De Rossi, G. B., 1979. Bovillae. Firenze: Leo Olschki.

Di Gennaro, F. et al., 2002. Recent Research on the City and Territory of Nepi (VT). Papers of the British School at Rome 70, 29-77.

Fugazzola Delpino, M.A., Pessina, A., and Tine', V., 2004. Il Neolitico in Italia. Roma: Itituto Italiano di Preistoria e Protostoria.

Enei, F., 2001. Progetto Ager Caeretanus. Il litorale di Alsium. Santa Marinella: Regione Lazio.

Felici, C. 2004. Pienza. Carta Archeologica della Provincia di Siena, VI. Siena: Nuova Immagine Editrice.

Fulminante, F., 2014. The Urbanisation of Rome and Latium Vetus. Cambridge: Cambridge University Press.

Gianfrotta, P. A., 1972. Castrum Novum. Forma Italiae, Regio VII -3. Roma: De Luca.

Giuliani, C. F. ,1966. Tibur II. Forma Italiae, 9. Roma: De Luca.

Hayes, J. W. and Martini, I. P., 1994. Archaeological Survey in the Lower Liri Valley, Central Italy. Oxford: Archaeopress (Bar International, 595).

Hemphill, P., 2000. Archaeological Investigations in Southern Etruria. The Civitella Cesi Survey. Motala: Motala Grafiska.

Holstrom, S., Voorripps \& H. Kamermans, 2004. The Agro Pontino archaeological survey. Leiden: University of Leiden.

Jolivet, V. et al., 2009. Suburbium II. Il Suburbio di Roma dalla fine dell'eta' monarchica alla nascita del sistema delle ville (V-II secolo a.C.). Rome: Ecole Francaise de Rome.

King, N., 1993. An Archaeological Field Survey Near Campagnano di Roma, Southern Etruria. Papers of the British School at Rome 61, 115-124.

Maffei, A., 2008. Carta Archeologica 'Arco del Mignone'.

Mari, Z., 1983. Tibur III. Forma Italiae, 31. Firenze: Leo Olschki.

Mari, Z., 1991. Tibur IV. Forma Italiae Regio I, 35. Firenze: Leo S. Olschki.

Mazzolani, M., 1969. Anagnia. Forma Italiae, 6. Roma: Istituto di Topografia Antica dell'Universita' di Roma.

Morselli, C., 1980. Sutrium. Forma Italiae, 7. Firenze: Leo Olschki.

Morselli, C. and Tortorici, E., 1982. Ardea. Forma Italiae, 16. Firenze: Leo Olschki.

Muzzioli, M. P., 1970. Praeneste. Forma Italiae Regio I, 8. Roma: Consiglio Nazionale delle Ricerche.

Muzzioli, M. P., 1980. Cures Sabini. Forma Italiae, Regio IV -2. Firenze: Leo Olschki. 
Nardi, G., 1980. Le Antichita’ di Orte. Roma: Consiglio Nazionale delle Ricerche.

Nardi, G., 1988. Definizione e perimetrazione del parco. In: Cristofani M. and Nardi, G. (eds.), Il Parco Archeologico. Roma: Consiglio Nazionale delle Ricerche, 65-73.

Neppi-Modena, A. (1953) Pisae. Forma Italiae, Regio VII -1. Rome: Unione Accademica Nazionale.

Pacciarelli, M., 2010. Dal villaggio alla citta'. La svolta protourbana del 1000 a.C. nell'Italia tirrenica. Firenze: All'Insegna del Giglio.

Pala, C., 1976. Nomentum. Forma Italiae, Regio I -12. Roma: De Luca.

Paolucci, G., 2007. Chianciano Terme. Carta Archeologica della Provincia di Siena, IX. Siena: Nuova Immagine Editrice.

Pasquinucci, M. and Menchelli, S., 1999. The Landscape and Economy of the Territories of Pisae and Volaterrae (Coastal North Etruria). Journal of Roman Archaeology 12, 123-141.

Perazzi, P. and Poggesi, G., 2011. Carta Archeologica della Provincia di Prato. Firenze: All'Insegna del Giglio.

Quilici, L., 1974. Collatia. Forma Italiae Regio I, 10. Roma: De Luca Editore.

Quilici Gigli, S., 1970. Tuscana. Forma Italiae, Regio VII -2. Roma: De Luca.

Quilici Gigli, S., 1976. Blera. Topografia antica della citta' e territorio. Mainz: Verlag Philipp Von Zabern.

Quilici, L. and Quilici Gigli, S., 1980. Crustumerium. Roma: Consiglio Nazionale delle Ricerche.

Quilici, L. and Quilici Gigli, S., 1986. Fidenae. Latium Vetus, 5. Roma: Consiglio Nazionale delle Ricerche.

Quilici, L. and Quilici Gigli, S., 1993. Ficulea. Latium Vetus, 6. Roma: Consiglio Nazionale delle Ricerche.

Provincia di Firenze, 1995. Carta Archeologica della Provincia di Firenze. Firenze: Provincia di Firenze.

Rajala, U., 2013. The concentration and centralization of late prehistoric settlement in central Italy: the evidence from the Nepi Survey, Papers of the British School at Rome 81, 1-38.

Schiappelli, A., 2008. Sviluppo storico della teverina. Nell' eta' del Bronzo e nella prima eta' del Ferro. Firenze: All'Insegna del Giglio.

Sewell, J. P. and Witcher, R. E., 2015. Urbanism in Ancient Peninsular Italy: developing a methodology for a database analysis of higher order settlements (350 $\mathrm{BCE}$ to $300 \mathrm{CE}$ ). Internet Archaeology 40.

Tartara, P., 1999. Torrimpietra. Forma Italiae, 1. Firenze: Leo S. Olschki. 
Valenti, M., 1995. Carta Archeologica della Provincia di Siena I. Chianti senese (Castellina in Chianti, Castelnuovo Berardenga, Gaiole in Chianti, Radda in Chianti). Siena: Nuova Immagine Editrice.

Valenti, M., 1999. Carta Archeologica della Provincia di Siena III. La Valdelsa (Comuni di Colle Val d'Elsa e Poggibonsi). Siena: Nuova Immagine Editrice .

Valenti, M., 2003. Ager Tusculanus. Forma Italiae, 41. Florence: Leo Olschki.

van Leusen, M., Tol, G. W. and Anastasia, C., 2010. Archaeological sites recorded by the GIA Hidden Landscapes survey campaigns in the Monti Lepini (Lazio, Italy), 2005-2009. Palaeohistoria, 51/52, 329-424.

van Loon, T., Willemsen, S. L. and Tol, G. W., 2014. Sites and finds of the Campoverde and Padiglione surveys of the Pontine region project (2005).

Palaeohistoria 55/56, 105-137.

Verga, F., 2006. Ager Foronovanus. Firenze: Leo S. Olschki.

Zecchini, M., 1999. Lucca Etrusca. Abitati, necropoli, luoghi di culto. Lucca: Edizioni S. Marco Litotipo. 


\begin{tabular}{|c|c|c|c|c|c|c|}
\hline $\begin{array}{c}\text { Time start } \\
\text { BP }\end{array}$ & $\begin{array}{l}\text { Time end } \\
\text { BP }\end{array}$ & $\begin{array}{c}\text { SPD of } \\
\text { radiocarbon } \\
\text { dates }\end{array}$ & Raw count & Total area & $\begin{array}{l}\text { Aoristic } \\
\text { weight }\end{array}$ & $\begin{array}{c}\text { Randomised } \\
\text { duration }\end{array}$ \\
\hline 10000 & 8000 & -0.21 & 0.74 & 0.74 & 0.76 & 0.61 \\
\hline 9800 & 7800 & -0.01 & 0.47 & 0.47 & 0.51 & 0.37 \\
\hline 9600 & 7600 & -0.01 & 0.42 & 0.42 & 0.43 & 0.37 \\
\hline 9400 & 7400 & -0.16 & 0.23 & 0.23 & 0.21 & 0.19 \\
\hline 9200 & 7200 & -0.37 & -0.13 & -0.13 & -0.13 & -0.15 \\
\hline 9000 & 7000 & -0.50 & -0.48 & -0.48 & -0.48 & -0.43 \\
\hline 8800 & 6800 & -0.71 & -0.81 & -0.81 & -0.80 & -0.76 \\
\hline 8600 & 6600 & -0.62 & -0.85 & -0.85 & -0.83 & -0.76 \\
\hline 8400 & 6400 & -0.48 & -0.86 & -0.86 & -0.81 & -0.77 \\
\hline 8200 & 6200 & -0.38 & -0.82 & -0.82 & -0.77 & -0.77 \\
\hline 8000 & 6000 & -0.35 & -0.82 & $*-0.68$ & -0.77 & -0.77 \\
\hline 7800 & 5800 & -0.38 & -0.81 & -0.54 & -0.78 & -0.84 \\
\hline 7600 & 5600 & -0.14 & -0.72 & -0.38 & -0.73 & -0.79 \\
\hline 7400 & 5400 & -0.38 & -0.74 & -0.40 & -0.75 & -0.72 \\
\hline 7200 & 5200 & -0.47 & -0.76 & -0.46 & -0.81 & -0.76 \\
\hline 7000 & 5000 & -0.19 & -0.50 & -0.12 & -0.53 & -0.55 \\
\hline 6800 & 4800 & 0.01 & -0.56 & 0.18 & -0.12 & -0.12 \\
\hline 6600 & 4600 & -0.16 & -0.41 & -0.04 & -0.19 & -0.22 \\
\hline 6400 & 4400 & -0.22 & -0.55 & 0.26 & 0.15 & 0.01 \\
\hline 6200 & 4200 & -0.14 & -0.36 & 0.29 & 0.33 & 0.09 \\
\hline 6000 & 4000 & -0.16 & -0.43 & 0.20 & 0.32 & 0.09 \\
\hline 5800 & 3800 & -0.16 & -0.28 & 0.15 & 0.28 & 0.05 \\
\hline 5600 & 3600 & -0.14 & -0.21 & 0.20 & 0.41 & -0.04 \\
\hline 5400 & 3400 & 0.02 & -0.08 & 0.21 & 0.50 & 0.01 \\
\hline 5200 & 3200 & 0.05 & 0.01 & -0.05 & 0.27 & 0.02 \\
\hline 5000 & 3000 & 0.10 & 0.04 & 0.05 & 0.38 & 0.18 \\
\hline 4800 & 2800 & -0.09 & 0.15 & -0.16 & 0.07 & 0.02 \\
\hline 4600 & 2600 & -0.07 & -0.27 & -0.53 & -0.26 & -0.15 \\
\hline 4400 & 2400 & -0.12 & -0.40 & -0.65 & -0.49 & -0.45 \\
\hline 4200 & 2200 & -0.03 & -0.57 & -0.76 & -0.66 & -0.60 \\
\hline 4000 & 2000 & 0.02 & -0.66 & -0.83 & -0.76 & -0.70 \\
\hline 3800 & 1800 & 0.26 & -0.81 & -0.93 & -0.87 & -0.83 \\
\hline 3600 & 1600 & 0.54 & -0.83 & -0.93 & -0.92 & -0.87 \\
\hline 3400 & 1400 & 0.54 & -0.81 & -0.78 & -0.87 & -0.87 \\
\hline
\end{tabular}

Table S1. Spearman's correlations between all archaeological proxies and arboreal (tree) pollen. Moving window results for central Italy for 200 year subsets of data in 2000-year moving time windows with time series shown in Figure S1: 1-5. The orange-blue scale values represent the statistical significance of correlation values, with orange representing $\mathrm{p}<0.05$, red $\mathrm{p}<0.01$, and blue $\mathrm{p}<0.001$. Strongest cross-correlation $\left({ }^{*} \operatorname{lag}-1\right.$; ${ }^{* *} \operatorname{lag}-2 ;{ }^{* * *} \operatorname{lag}+1$; no asterisk lag 0). 


\begin{tabular}{|c|c|c|c|c|c|c|}
\hline $\begin{array}{c}\text { Time start } \\
\text { BP }\end{array}$ & $\begin{array}{l}\text { Time end } \\
\text { BP }\end{array}$ & $\begin{array}{c}\text { SPD of } \\
\text { radiocarbon } \\
\text { dates }\end{array}$ & Raw count & Total area & $\begin{array}{l}\text { Aoristic } \\
\text { weight }\end{array}$ & $\begin{array}{c}\text { Randomised } \\
\text { duration }\end{array}$ \\
\hline 10000 & 8000 & -0.37 & 0.62 & 0.62 & 0.62 & 0.61 \\
\hline 9800 & 7800 & 0.04 & 0.70 & 0.70 & 0.69 & 0.73 \\
\hline 9600 & 7600 & 0.20 & 0.57 & 0.57 & 0.60 & 0.64 \\
\hline 9400 & 7400 & 0.05 & 0.37 & 0.37 & 0.43 & 0.41 \\
\hline 9200 & 7200 & -0.14 & 0.10 & 0.10 & 0.19 & 0.08 \\
\hline 9000 & 7000 & -0.48 & -0.31 & -0.31 & -0.16 & -0.38 \\
\hline 8800 & 6800 & -0.52 & -0.24 & -0.24 & -0.10 & -0.35 \\
\hline 8600 & 6600 & -0.73 & -0.56 & -0.56 & -0.38 & -0.71 \\
\hline 8400 & 6400 & -0.52 & -0.06 & -0.06 & 0.03 & -0.22 \\
\hline 8200 & 6200 & -0.13 & 0.35 & 0.35 & 0.29 & 0.12 \\
\hline 8000 & 6000 & 0.16 & 0.64 & 0.58 & 0.54 & 0.41 \\
\hline 7800 & 5800 & 0.04 & 0.27 & 0.53 & 0.18 & 0.13 \\
\hline 7600 & 5600 & 0.14 & 0.27 & 0.47 & 0.12 & 0.14 \\
\hline 7400 & 5400 & 0.27 & 0.25 & 0.41 & 0.07 & 0.08 \\
\hline 7200 & 5200 & -0.05 & -0.06 & 0.18 & -0.25 & -0.26 \\
\hline 7000 & 5000 & -0.25 & -0.32 & -0.08 & -0.55 & -0.53 \\
\hline 6800 & 4800 & -0.37 & -0.28 & -0.18 & -0.60 & -0.70 \\
\hline 6600 & 4600 & -0.47 & -0.25 & -0.22 & -0.56 & -0.71 \\
\hline 6400 & 4400 & -0.26 & -0.12 & -0.20 & -0.41 & -0.55 \\
\hline 6200 & 4200 & -0.25 & 0.19 & 0.08 & -0.09 & -0.53 \\
\hline 6000 & 4000 & -0.25 & -0.07 & 0.23 & -0.09 & -0.28 \\
\hline 5800 & 3800 & -0.49 & -0.02 & -0.03 & -0.35 & -0.42 \\
\hline 5600 & 3600 & -0.33 & 0.01 & 0.07 & -0.24 & -0.37 \\
\hline 5400 & 3400 & -0.32 & -0.25 & 0.10 & -0.03 & -0.13 \\
\hline 5200 & 3200 & -0.01 & 0.04 & 0.12 & -0.07 & -0.13 \\
\hline 5000 & 3000 & 0.37 & 0.23 & 0.15 & -0.04 & -0.13 \\
\hline 4800 & 2800 & 0.50 & 0.19 & 0.39 & 0.22 & 0.16 \\
\hline 4600 & 2600 & 0.52 & 0.40 & $* * * 0.59$ & 0.47 & 0.38 \\
\hline 4400 & 2400 & 0.55 & 0.48 & $* * * 0.67$ & 0.64 & 0.60 \\
\hline 4200 & 2200 & 0.41 & 0.62 & 0.76 & 0.75 & 0.75 \\
\hline 4000 & 2000 & 0.37 & 0.78 & 0.90 & 0.90 & 0.90 \\
\hline 3800 & 1800 & 0.01 & 0.72 & 0.84 & 0.84 & 0.85 \\
\hline 3600 & 1600 & -0.41 & 0.72 & 0.79 & 0.75 & 0.79 \\
\hline 3400 & 1400 & -0.42 & 0.64 & 0.64 & 0.64 & 0.78 \\
\hline
\end{tabular}

Table S2. Spearman's correlations between all archaeological proxies and Oleaceae pollen. Moving window results for central Italy for 200 year subsets of data in 2000-year moving time windows with time series shown in Figure S1: 11-15. The orange-blue scale values represent the statistical significance of correlation values, with orange representing $\mathrm{p}<0.05$, red $\mathrm{p}<0.01$, and blue $\mathrm{p}<0.001$. Strongest cross-correlation $\left({ }^{*} \operatorname{lag}-1\right.$; ${ }^{* *} \operatorname{lag}-2 ;{ }^{* * *} \operatorname{lag}+1$; no asterisk lag 0). 


\begin{tabular}{|c|c|c|c|c|c|c|}
\hline $\begin{array}{c}\text { Time start } \\
\text { BP }\end{array}$ & $\begin{array}{l}\text { Time end } \\
\text { BP }\end{array}$ & $\begin{array}{c}\text { SPD of } \\
\text { radiocarbon } \\
\text { dates }\end{array}$ & Raw count & Total area & $\begin{array}{l}\text { Aoristic } \\
\text { weight }\end{array}$ & $\begin{array}{l}\text { Randomised } \\
\text { duration }\end{array}$ \\
\hline 10000 & 8000 & -0.49 & 0.38 & 0.38 & 0.39 & 0.41 \\
\hline 9800 & 7800 & -0.37 & 0.25 & 0.25 & 0.28 & 0.28 \\
\hline 9600 & 7600 & -0.03 & 0.20 & 0.20 & 0.22 & 0.38 \\
\hline 9400 & 7400 & -0.28 & -0.03 & -0.03 & 0.00 & 0.13 \\
\hline 9200 & 7200 & -0.12 & 0.23 & 0.23 & 0.18 & 0.35 \\
\hline 9000 & 7000 & -0.45 & -0.17 & -0.17 & -0.19 & -0.10 \\
\hline 8800 & 6800 & -0.55 & -0.24 & -0.24 & -0.24 & -0.21 \\
\hline 8600 & 6600 & -0.82 & -0.57 & -0.57 & -0.58 & -0.55 \\
\hline 8400 & 6400 & -0.68 & -0.12 & -0.12 & -0.22 & -0.14 \\
\hline 8200 & 6200 & -0.38 & 0.20 & 0.20 & 0.01 & 0.12 \\
\hline 8000 & 6000 & -0.22 & 0.36 & 0.32 & 0.16 & 0.27 \\
\hline 7800 & 5800 & -0.32 & -0.03 & 0.19 & -0.13 & -0.13 \\
\hline 7600 & 5600 & -0.10 & 0.13 & 0.46 & 0.01 & 0.04 \\
\hline 7400 & 5400 & -0.04 & 0.01 & 0.30 & -0.13 & -0.12 \\
\hline 7200 & 5200 & -0.09 & -0.01 & 0.31 & -0.18 & -0.18 \\
\hline 7000 & 5000 & -0.35 & -0.37 & -0.05 & -0.59 & -0.56 \\
\hline 6800 & 4800 & -0.41 & -0.23 & -0.19 & -0.62 & -0.75 \\
\hline 6600 & 4600 & -0.39 & -0.22 & -0.17 & -0.52 & -0.65 \\
\hline 6400 & 4400 & -0.18 & -0.10 & -0.06 & -0.25 & -0.41 \\
\hline 6200 & 4200 & -0.10 & 0.20 & 0.15 & 0.04 & -0.37 \\
\hline 6000 & 4000 & -0.02 & 0.15 & 0.45 & 0.10 & -0.21 \\
\hline 5800 & 3800 & -0.56 & -0.11 & $\sqrt{2}$ & -0.28 & -0.24 \\
\hline 5600 & 3600 & -0.45 & -0.06 & -0.15 & -0.48 & -0.32 \\
\hline 5400 & 3400 & -0.54 & -0.30 & -0.05 & -0.24 & -0.10 \\
\hline 5200 & 3200 & -0.07 & 0.04 & 0.17 & 0.01 & -0.01 \\
\hline 5000 & 3000 & 0.07 & 0.17 & 0.04 & -0.15 & -0.27 \\
\hline 4800 & 2800 & 0.28 & 0.07 & 0.22 & 0.08 & -0.09 \\
\hline 4600 & 2600 & 0.37 & 0.27 & 0.43 & 0.33 & 0.21 \\
\hline 4400 & 2400 & 0.36 & 0.42 & 0.58 & 0.50 & 0.45 \\
\hline 4200 & 2200 & 0.25 & 0.55 & 0.68 & $* 0.65$ & $* * * 0.62$ \\
\hline 4000 & 2000 & 0.14 & 0.65 & $* * * 0.75$ & 0.72 & $* * * 0.72$ \\
\hline 3800 & 1800 & -0.10 & 0.67 & $* * * 0.73$ & 0.72 & 0.76 \\
\hline 3600 & 1600 & -0.43 & 0.62 & $* * * 0.64$ & 0.66 & 0.64 \\
\hline 3400 & 1400 & -0.47 & 0.55 & 0.50 & 0.58 & 0.61 \\
\hline
\end{tabular}

Table S3. Spearman's correlations between all archaeological proxies and OJC (Olea, Juglans, Castanea) pollen. Moving window results for central Italy for 200 year subsets of data in 2000-year mowing time windows with time series shown in Figure S1: 15-20. The orangeblue scale values represent the statistical significance of correlation values, with orange representing $\mathrm{p}<0.05$, red $\mathrm{p}<0.01$, and blue $\mathrm{p}<0.001$. Strongest cross-correlation $\left({ }^{*}\right.$ lag -1 ; ${ }^{* *}$ lag -2 ; ${ }^{* * *}$ lag +1 ; no asterisk lag 0 ). 


\begin{tabular}{|c|c|c|c|c|c|c|}
\hline $\begin{array}{c}\text { Time start } \\
\text { BP }\end{array}$ & $\begin{array}{l}\text { Time end } \\
\text { BP }\end{array}$ & $\begin{array}{c}\text { SPD of } \\
\text { radiocarbon } \\
\text { dates }\end{array}$ & Raw count & Total area & $\begin{array}{l}\text { Aoristic } \\
\text { weight }\end{array}$ & $\begin{array}{c}\text { Randomised } \\
\text { duration }\end{array}$ \\
\hline 10000 & 8000 & -0.33 & 0.26 & 0.26 & 0.31 & 0.37 \\
\hline 9800 & 7800 & -0.21 & 0.26 & 0.26 & 0.30 & 0.36 \\
\hline 9600 & 7600 & 0.04 & 0.33 & 0.33 & 0.33 & 0.50 \\
\hline 9400 & 7400 & -0.07 & 0.20 & 0.20 & 0.19 & 0.44 \\
\hline 9200 & 7200 & 0.02 & 0.32 & 0.32 & 0.26 & 0.53 \\
\hline 9000 & 7000 & -0.20 & 0.05 & 0.05 & 0.00 & 0.25 \\
\hline 8800 & 6800 & -0.43 & -0.32 & -0.32 & -0.36 & -0.13 \\
\hline 8600 & 6600 & -0.64 & -0.70 & -0.70 & -0.77 & -0.49 \\
\hline 8400 & 6400 & -0.45 & -0.28 & -0.28 & -0.44 & -0.08 \\
\hline 8200 & 6200 & -0.01 & 0.15 & 0.15 & -0.23 & 0.19 \\
\hline 8000 & 6000 & 0.13 & 0.31 & 0.24 & -0.07 & 0.31 \\
\hline 7800 & 5800 & -0.02 & -0.06 & 0.10 & -0.30 & -0.14 \\
\hline 7600 & 5600 & -0.09 & -0.18 & 0.20 & -0.34 & -0.25 \\
\hline 7400 & 5400 & 0.03 & -0.02 & 0.36 & -0.18 & -0.24 \\
\hline 7200 & 5200 & -0.20 & -0.23 & 0.18 & -0.42 & -0.48 \\
\hline 7000 & 5000 & -0.30 & -0.37 & 0.08 & -0.58 & -0.72 \\
\hline 6800 & 4800 & -0.27 & $\begin{array}{r}-0.09 \\
\end{array}$ & -0.14 & -0.62 & -0.87 \\
\hline 6600 & 4600 & -0.22 & -0.09 & -0.15 & -0.53 & -0.76 \\
\hline 6400 & 4400 & -0.08 & 0.03 & -0.04 & -0.22 & -0.52 \\
\hline 6200 & 4200 & 0.01 & 0.33 & 0.16 & 0.05 & -0.48 \\
\hline 6000 & 4000 & 0.09 & 0.26 & 0.46 & 0.12 & -0.35 \\
\hline 5800 & 3800 & -0.45 & -0.02 & 0.05 & -0.27 & -0.37 \\
\hline 5600 & 3600 & -0.72 & 0.21 & 0.18 & -0.28 & -0.30 \\
\hline 5400 & 3400 & -0.76 & 0.15 & 0.36 & -0.05 & -0.12 \\
\hline 5200 & 3200 & -0.50 & 0.30 & 0.44 & 0.03 & -0.01 \\
\hline 5000 & 3000 & -0.28 & 0.36 & 0.49 & 0.07 & -0.04 \\
\hline 4800 & 2800 & 0.01 & 0.27 & 0.62 & 0.35 & 0.12 \\
\hline 4600 & 2600 & 0.19 & 0.38 & 0.73 & 0.50 & 0.44 \\
\hline 4400 & 2400 & 0.16 & 0.20 & 0.62 & 0.49 & 0.49 \\
\hline 4200 & 2200 & 0.02 & 0.43 & 0.61 & 0.50 & 0.54 \\
\hline 4000 & 2000 & -0.15 & 0.24 & 0.42 & 0.28 & 0.33 \\
\hline 3800 & 1800 & -0.19 & 0.18 & 0.36 & 0.22 & 0.28 \\
\hline 3600 & 1600 & -0.07 & 0.27 & 0.45 & 0.47 & 0.44 \\
\hline 3400 & 1400 & -0.14 & 0.08 & 0.18 & 0.20 & 0.25 \\
\hline
\end{tabular}

Table S4. Spearman's correlations between all archaeological proxies and OJCV (Olea, Juglans, Castanea, Vitis) pollen. Moving window results for central Italy for 200 year subsets of data in 2000-year moving time windows with time series shown in Figure S2: 1-5. The orange-blue scale values represent the statistical significance of correlation values, with orange representing $\mathrm{p}<0.05$, red $\mathrm{p}<0.01$, and blue $\mathrm{p}<0.001$. Strongest cross-correlation $\left({ }^{*}\right.$ lag $-1 ;{ }^{* *} \operatorname{lag}$ -2 ; ${ }^{* * *}$ lag +1 ; no asterisk lag 0 ). 


\begin{tabular}{|c|c|c|c|c|c|c|}
\hline $\begin{array}{c}\text { Time start } \\
\text { BP }\end{array}$ & $\begin{array}{l}\text { Time end } \\
\text { BP }\end{array}$ & $\begin{array}{c}\text { SPD of } \\
\text { radiocarbon } \\
\text { dates }\end{array}$ & Raw count & Total area & $\begin{array}{c}\text { Aoristic } \\
\text { weight }\end{array}$ & $\begin{array}{c}\text { Randomised } \\
\text { duration }\end{array}$ \\
\hline 10000 & 8000 & -0.08 & -0.46 & -0.46 & -0.52 & -0.16 \\
\hline 9800 & 7800 & -0.55 & -0.43 & -0.43 & -0.49 & -0.31 \\
\hline 9600 & 7600 & -0.37 & -0.56 & -0.56 & -0.62 & -0.28 \\
\hline 9400 & 7400 & -0.49 & -0.64 & -0.64 & -0.68 & -0.51 \\
\hline 9200 & 7200 & -0.33 & -0.48 & -0.48 & -0.54 & -0.24 \\
\hline 9000 & 7000 & -0.39 & -0.38 & -0.38 & -0.45 & -0.13 \\
\hline 8800 & 6800 & -0.42 & -0.28 & -0.28 & -0.35 & -0.16 \\
\hline 8600 & 6600 & -0.28 & 0.12 & 0.12 & 0.02 & 0.27 \\
\hline 8400 & 6400 & -0.27 & 0.27 & 0.27 & 0.14 & 0.36 \\
\hline 8200 & 6200 & -0.09 & 0.47 & 0.47 & 0.34 & 0.56 \\
\hline 8000 & 6000 & 0.07 & 0.58 & 0.39 & 0.47 & 0.66 \\
\hline 7800 & 5800 & -0.18 & 0.24 & 0.21 & 0.26 & 0.20 \\
\hline 7600 & 5600 & 0.07 & 0.38 & 0.10 & 0.39 & 0.23 \\
\hline 7400 & 5400 & 0.28 & 0.41 & 0.07 & 0.43 & 0.11 \\
\hline 7200 & 5200 & 0.26 & 0.44 & 0.17 & 0.42 & 0.02 \\
\hline 7000 & 5000 & 0.04 & 0.19 & -0.11 & 0.09 & -0.17 \\
\hline 6800 & 4800 & -0.14 & 0.25 & -0.32 & -0.20 & -0.42 \\
\hline 6600 & 4600 & 0.04 & 0.15 & -0.12 & -0.05 & -0.08 \\
\hline 6400 & 4400 & 0.03 & 0.14 & 0.06 & 0.10 & 0.05 \\
\hline 6200 & 4200 & -0.09 & 0.21 & 0.12 & 0.05 & -0.05 \\
\hline 6000 & 4000 & -0.09 & -0.05 & 0.29 & 0.05 & 0.06 \\
\hline 5800 & 3800 & -0.62 & -0.30 & -0.16 & -0.37 & -0.05 \\
\hline 5600 & 3600 & $* * *-0.76$ & -0.13 & -0.10 & -0.41 & -0.06 \\
\hline 5400 & 3400 & $* * *-0.78$ & -0.23 & 0.01 & -0.19 & 0.06 \\
\hline 5200 & 3200 & -0.30 & 0.04 & 0.24 & 0.07 & 0.17 \\
\hline 5000 & 3000 & 0.09 & 0.23 & 0.41 & 0.27 & 0.28 \\
\hline 4800 & 2800 & 0.36 & 0.12 & 0.56 & 0.50 & 0.38 \\
\hline 4600 & 2600 & 0.56 & 0.00 & 0.50 & 0.45 & 0.28 \\
\hline 4400 & 2400 & 0.58 & -0.24 & 0.26 & 0.21 & -0.22 \\
\hline 4200 & 2200 & 0.45 & 0.13 & 0.26 & 0.19 & 0.02 \\
\hline 4000 & 2000 & 0.48 & 0.18 & 0.32 & 0.25 & 0.08 \\
\hline 3800 & 1800 & 0.48 & -0.09 & 0.05 & -0.02 & -0.15 \\
\hline 3600 & 1600 & 0.14 & -0.09 & 0.02 & -0.13 & -0.10 \\
\hline 3400 & 1400 & 0.19 & -0.32 & -0.37 & -0.49 & -0.25 \\
\hline
\end{tabular}

Table S5. Spearman's correlations between all archaeological proxies and API (Anthropogenic Pollen Index). Moving window results for central Italy for 200 year subsets of data in 2000-year moving time windows with time series shown in Figure S2: 6-10. The orange-blue scale values represent the statistical significance of correlation values, with orange representing $\mathrm{p}<0.05$, red $\mathrm{p}<0.01$, and blue $\mathrm{p}<0.001$. Strongest cross-correlation $\left({ }^{*} \operatorname{lag}-\right.$ $1 ;{ }^{* *}$ lag $-2 ;{ }^{* * *}$ lag +1 ; no asterisk lag 0 ). 


\begin{tabular}{|c|c|c|c|c|c|c|}
\hline $\begin{array}{c}\text { Time start } \\
\text { BP }\end{array}$ & $\begin{array}{l}\text { Time end } \\
\text { BP }\end{array}$ & $\begin{array}{c}\text { SPD of } \\
\text { radiocarbon } \\
\text { dates }\end{array}$ & Raw count & Total area & $\begin{array}{l}\text { Aoristic } \\
\text { weight }\end{array}$ & $\begin{array}{c}\text { Randomised } \\
\text { duration }\end{array}$ \\
\hline 10000 & 8000 & 0.30 & 0.24 & 0.24 & 0.20 & 0.39 \\
\hline 9800 & 7800 & 0.10 & 0.35 & 0.35 & 0.30 & 0.52 \\
\hline 9600 & 7600 & 0.39 & 0.33 & 0.33 & 0.28 & 0.59 \\
\hline 9400 & 7400 & 0.25 & 0.10 & 0.10 & 0.04 & 0.41 \\
\hline 9200 & 7200 & 0.01 & -0.26 & -0.26 & -0.30 & 0.20 \\
\hline 9000 & 7000 & 0.14 & -0.15 & -0.15 & -0.23 & 0.31 \\
\hline 8800 & 6800 & -0.12 & -0.40 & -0.40 & -0.48 & 0.01 \\
\hline 8600 & 6600 & 0.05 & 0.02 & 0.02 & -0.09 & 0.33 \\
\hline 8400 & 6400 & 0.26 & 0.54 & 0.54 & 0.38 & 0.71 \\
\hline 8200 & 6200 & 0.43 & 0.77 & 0.77 & 0.61 & 0.88 \\
\hline 8000 & 6000 & 0.39 & 0.77 & 0.61 & 0.61 & 0.88 \\
\hline 7800 & 5800 & 8 & 0.53 & 0.46 & 0.48 & 0.58 \\
\hline 7600 & 5600 & 0.28 & 0.53 & 0.48 & 0.50 & 0.55 \\
\hline 7400 & 5400 & 0.45 & 0.56 & 0.51 & 0.52 & 0.43 \\
\hline 7200 & 5200 & 0.45 & 0.57 & 0.51 & 0.54 & 0.43 \\
\hline 7000 & 5000 & 0.56 & 0.65 & 0.59 & 0.65 & 0.36 \\
\hline 6800 & 4800 & 0.56 & 0.52 & 0.50 & 0.59 & 0.13 \\
\hline 6600 & 4600 & 0.71 & 0.36 & 0.59 & 0.65 & 0.28 \\
\hline 6400 & 4400 & 0.75 & 0.38 & 0.39 & 0.47 & 0.16 \\
\hline 6200 & 4200 & 0.76 & 0.17 & 0.08 & 0.26 & 0.16 \\
\hline 6000 & 4000 & 0.52 & -0.09 & 0.08 & 0.16 & 0.30 \\
\hline 5800 & 3800 & 0.14 & -0.20 & -0.29 & -0.20 & 0.22 \\
\hline 5600 & 3600 & -0.04 & -0.22 & -0.63 & -0.64 & 0.10 \\
\hline 5400 & 3400 & -0.12 & -0.30 & -0.60 & -0.60 & 0.09 \\
\hline 5200 & 3200 & -0.32 & -0.49 & -0.40 & -0.47 & 0.02 \\
\hline 5000 & 3000 & -0.32 & -0.54 & -0.34 & -0.41 & -0.04 \\
\hline 4800 & 2800 & -0.36 & -0.58 & -0.42 & -0.42 & -0.20 \\
\hline 4600 & 2600 & -0.28 & -0.47 & -0.25 & -0.32 & -0.20 \\
\hline 4400 & 2400 & -0.26 & -0.19 & -0.02 & -0.04 & 0.10 \\
\hline 4200 & 2200 & -0.37 & -0.15 & -0.15 & -0.19 & -0.31 \\
\hline 4000 & 2000 & -0.16 & -0.25 & -0.26 & -0.30 & -0.41 \\
\hline 3800 & 1800 & -0.16 & 0.08 & 0.07 & 0.03 & 0.02 \\
\hline 3600 & 1600 & -0.18 & 0.18 & 0.21 & 0.21 & 0.22 \\
\hline 3400 & 1400 & -0.42 & 0.10 & 0.15 & 0.12 & 0.09 \\
\hline
\end{tabular}

Table S6. Spearman's correlations between all archaeological proxies and regional pastoral indicators. Moving window results for central Italy for 200 year subsets of data in 2000-year moving time windows with time series shown in Figure S2: 11-15. The orange-blue scale values represent the statistical significance of correlation values, with orange representing $\mathrm{p}<0.05$, red $\mathrm{p}<0.01$, and blue $\mathrm{p}<0.001$. Strongest cross-correlation $\left({ }^{*} \operatorname{lag}-1 ;{ }^{* *} \operatorname{lag}-2 ;{ }^{* * *} \operatorname{lag}+1\right.$; no asterisk lag 0 ). 
